\title{
PENGARUH PEMASARAN EKSPERIENSIAL TERHADAP RETENSI PELANGGAN PADA PENGUNJUNG RESORT\&SPA KAMPUNG SAMPIREUN GARUT
}

\author{
Ratih Hurriyati \\ Irna Widiastuti
}

\begin{abstract}
Abstrak
Peran sektor bisnis dibidang hospitallity industry yang mencakup bisnis travel, tourism dan hotel memberikan peluang pasar yang cukup luas sehingga mendorong berdirinya berbagai usaha sarana pariwisata seperti hotel (resort). Munculnya resort-resort di Kota Garut dengan berbagai fasilitas dan penawaran produkJjasa yang menarik menimbulkan persaingan yang cukup ketat karena mendorong konsumen untuk berpindah, sehingga tidak ada keterikatan yang menentukan tingkat kesetiaan/loyalitas. Berbagai strategi diterapkan untuk mempertahankan pelanggan (retensi) agar tetap loyal dan retensi pelanggan lebih meningkat. Salah satu strategi atau upaya mempertahankan pelanggan apabila terciptanya pengalaman yang unik dan berkesan di setiap interaksi dengan pelanggan sebagai pembeda merek perusahaan yaitu melalui pendekatan emotional dengan menerapkan pemasaran eksperiensial. Tujuan penelitian ini untuk mendeskripsikan pelaksanaan pemasaran eksperiensial yang terdiri dari dimensi sense, feel, think, act, dan relate pada pengunjung Resort\&Spa Kampung Sampireun Garut; mendeskripsikan pelaksanaan retensi pelanggan yang terdiri dari dimensi trust, satisfaction, dan commitment pada pengunjung Resort\&Spa Kampung Sampireun Garut; serta menjelaskan seberapa besar pengaruh pemasaran eksperiensial yang terdiri dari sense, feel, think, act, dan relate terhadap retensi pelanggan pada pengunjung Resort\&Spa Kampung Sampireun Garut.

Berdasarkan variabel yang diteliti maka jenis penelitian ini adalah penelitian deskriptif dan verifikatif. Metode yang digunakan explanatory survey. Jangka waktu penelitian bersifat cross sectional method. Populasi penelitian ini ialah pengunjung atau tamu resort \& spa Kampung Sampireun Garut, yang rata-rata mencapai 3.538 orang per tahun. Berdasarkan teknik penarikan sampel secara systematic random sampling dan dengan menggunakan rumus Harun Al Rasyid diperoleh sampel sebesar 58 sampel, namun untuk meningkatkan keakuratan maka jumlah sampel yang diteliti ditambah sehingga berjumlah 60 sampel. Teknik Analisis data yang digunakan adalah analisi jalur (path analysis) dengan alat bantu software komputer SPSS 15.0. Data yang digunakan adalah data primer dan sekunder dengan teknik pengumpulan data melalui wawancara dengan staf resort, observasi langsung ke resort \& spa Kampung Sampireun, penyebaran angket penelitian, dan studi literatur.

Hasil penelitian menunjukkan pemasaran eksperiensial resort\&spa Kampung Sampireun berkategori sudah baik dengan indikator yang paling dominan berupa sense, sedangkan indikator yang paling rendah adalah relate. Retensi pelanggan pada resort\&spa Kampung Sampireun hampir seluruhnya sudah baik dengan indikator yang paling dominan adalah trust, sedangkan indikator yang paling rendah adalah satisfaction. Pemasaran eksperiensial berpengaruh secara positif terhadap retensi pelanggan. Sehingga produk dan jasa yang berkualitas, inovatif dan memberikan kenyamanan juga kepuasan yang baik pada pengunjung akan memberikan pengaruh yang positif terhadap retensi pelanggan.
\end{abstract}

\section{Kata Kunci: Pemasaran Eksperensial dan Retensi Pelanggan}

\section{PENDAHULUAN}

Dunia bisnis di era globalisasi ini menjadi sebuah tantangan bagi setiap dunia usaha untuk meningkatkan kinerja dan kualitas bisnisnya agar dapat bertahan dalam persaingan seperti saat ini. Perubahan seperti teknologi, ekonomi dan kondisi situasi pasar makin terlihat nyata hampir di setiap sektor industri.

Perubahan ekonomi dan kondisi sosial tersebut telah merubah pula sikap dan tingkah laku konsumen. Pemilihan akan produk dan jasa telah menjadi posisi tertinggi dalam pemasaran, konsumen tidak lagi hanya mengharapkan kualitas

Pengaruh Pemasaran Eksperensial terhadap Retensi Pelanggan pada Pengunjung Resort\&Spa Kampung Sampireun Garut 


\section{StrategiC}

yang tinggi dari produk/jasa itu sendiri, tetapi juga manfaat yang akan mereka terima dari produk/jasa tersebut.

Ketatnya persaingan pada dunia bisnis hampir terjadi pada seluruh industri dan jasa termasuk di dalamnya industri perhotelan/resort, para produsen dalam industri ini dituntut untuk melakukan terobosan bisnis yang baru agar dapat menggungguli para pesaingnya dan harus senantiasa selalu melakukan pengembangan terhadap produk-produknya secara optimal, serta mengetahui apa yang dibutuhkan oleh konsumen, sehingga kepuasan pelanggan selalu terjaga dan pelanggan tidak akan merasa bosan. Adapun perkiraan pertumbuhan pasar industri yang ada pada Tahun 2005-2007 dapat dilihat pada Tabel 1 di bawah ini
2007 pangsa pasar industri perhotelan mengalami kenaikan menjadi $7,3 \%$. Kondisi ini menjanjikan keuntungan ekonomi pada bisnis jasa penginapan, perhotelan/resort sebagai tempat menginap. Berikut akan disajikan tentang tingkat penghunian kamar hotel di 10 propinsi daerah tujuan wisata Tahun 2005-2007.

Tingkat perkembangan kamar hotel selama Tahun 2005-2007 dari masing-masing daerah tujuan wisata mengalami fluktuatif, seperti di Jawa Barat. Tahun 2005 tingkan penghunian kamar sebesar 37,00\%, Tahun 2006 turun menjadi 35,37\% dan pada Tahun 2007 mengalami kenaikan menjadi $42,82 \%$. Hal ini menunjukkan bahwa Jawa Barat mempunyai potensi tempat wisata yang diminati wisatawan.

Tabel 1

Tabel Pertumbuhan Market Size Beberapa Sektor Industri tahun 2005-2007

\begin{tabular}{|c|c|c|c|c|c|c|c|}
\hline \multirow{2}{*}{ No } & \multirow{2}{*}{ Sektor } & \multicolumn{3}{|c|}{ Nominal } & \multicolumn{3}{|c|}{ Pertumbuhan (\%) } \\
\hline & & 2005 & 2006 & 2007 & $2005 \mathrm{~F}$ & 2006F & $2007 \mathrm{~F}$ \\
\hline 1 & Penerbangan (Rp milyar) & $10.362,3$ & $11.515,8$ & $13.744,8$ & 10,4 & 11,1 & 19,4 \\
\hline 2 & Biro Perjalanan (Rp milyar) & $15.902,9$ & $17.342,1$ & $20.016,1$ & 5,6 & 9,1 & 15,4 \\
\hline 3 & Perhotelan/Resort (Rp milyar) & $12.365,6$ & $12.694,4$ & $13.621,4$ & 6,7 & 2,7 & 7,3 \\
\hline 4 & Restoran dan Industri Fastfood & $39.648,1$ & $42.368,9$ & $44.640,1$ & 6,4 & 2,7 & 7,3 \\
\hline 5 & Departemen Store(Rp milyar) & $11.216,4$ & $13.408,9$ & $16.062,8$ & 19,1 & 19,5 & 19,8 \\
\hline 6 & Asuransi (Rp milyar (sales) & $4.260,1$ & $5.079,2$ & $6.104,9$ & 12,4 & 19,2 & 20,2 \\
\hline \multirow[t]{3}{*}{7} & Otomotif & & & & & & \\
\hline & Mobil (sales) (Ribu unit) & 533,9 & 309,7 & 415,6 & 10,5 & $-42,0$ & 34,2 \\
\hline & Motor (Ribu unit) & 5,1 & 4,1 & 5,0 & 30,5 & $-18,6$ & 20,8 \\
\hline 8 & $\begin{array}{l}\text { Perbankan (Rp triliun) (Penyaluran } \\
\text { kredit) }\end{array}$ & 689,7 & 831,4 & $1.028,0$ & 24,6 & 20,6 & 23,6 \\
\hline 9 & $\begin{array}{l}\text { Tekstil dan Garmen (Rp milyar) } \\
\text { (sales) }\end{array}$ & $4.246,4$ & $4.009,5$ & $4.204,8$ & 8,5 & $-5,6$ & 4,9 \\
\hline 10 & Farmasi (Rp triliun) (sales) & $3.038,4$ & $3.283,0$ & $3.661,9$ & 8,5 & 8,1 & 11,5 \\
\hline 11 & Kosmetik dan toiletries (Rp milyar) & 10200,2 & $11.568,1$ & $13.203,3$ & 10,5 & 13,4 & 14,1 \\
\hline 12 & Rokok (Milyar Batang) & 225,5 & 240,8 & 255,6 & 5,4 & 6,8 & 6,2 \\
\hline 13 & $\begin{array}{l}\text { Makanan dan Minuman (Rp } \\
\text { milyar) }\end{array}$ & $121.377,9$ & $123.066,1$ & $124.663,8$ & 2,7 & 1,4 & 1,3 \\
\hline 14 & $\begin{array}{l}\text { Properti dan Real Estate (Rp } \\
\text { milyar) (sales) }\end{array}$ & $9.679,9$ & $11.751,9$ & $14.245,2$ & 26,9 & 20,3 & 21,2 \\
\hline \multirow[t]{3}{*}{15} & Telekomunikasi & & & & & & \\
\hline & $\begin{array}{l}\text { Jumlah Pelanggan seluler (Rp } \\
\text { juta) }\end{array}$ & 45,7 & 59,0 & 75,8 & 53,1 & 29,2 & 28,4 \\
\hline & $\begin{array}{l}\text { Jumlah saluran terpasang (Rp } \\
\text { Juta) }\end{array}$ & 12,7 & 14,4 & 15,9 & 27,6 & 12,8 & 10,7 \\
\hline
\end{tabular}

Sumber: Dana Reksa Research Institute (Majalah SWA No 01/XXIII/14 - 17 Januari 2008)

Berdasarkan Tabel 1.1 di atas industri perhotelan (resort) mengalami perubahan yang fluktuatif dari Tahun 2005 sampai Tahun 2007. Tahun 2005 memperoleh pangsa pasar 6,7\% di tahun 2006 turun menjadi 2,7\% dan pada Tahun
Salah satu daerah di Jawa Barat yang menjadi tujuan wisata adalah Kota Garut. Tingginya tingkat persaingan perhotelan/resort di Kota Garut ini perlu diperhatikan oleh perusahaan yang bergerak dalam industri perhotelan/resort untuk dapat 


\section{StrategiC}

mempertahankan pelanggan dan meningkatkan pangsa pasarnya.

Berikut akan diperlihatkan data mengenai jumlah pengunjung resort-resort yang ada di Kota Garut.

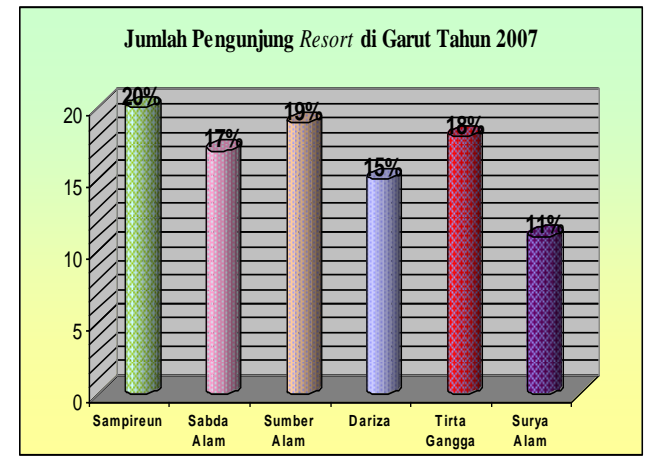

Sumber Data : Kampung Sampireun Garut, 2008 Gambar 1

Pangsa Pasar Resort di Garut

Berdasarkan Gambar 1 di atas, jumlah pengunjung resort-resort di Kota Garut bersaing dengan ketat terlihat dari pengunjung yang datang hampir merata di semua resort. Kampung Sampireun dengan jumlah pengunjung yang datang sebesar $20 \%$, Sabda Alam sebesar $17 \%$, Sumber Alam sebesar 19\%, Dariza 15\%, Tirta Gangga 18\% dan Surya Alam sebesar $11 \%$.

Membuat konsumen tertarik akan produk dan pelayanan resort bukanlah hal yang mudah, karena pada masa kini konsumen akan memilih produk dan pelayanan dari resort yang benarbenar mereka percayai dapat menawarkan nilai tertinggi dan konsumen juga mengharapakan lebih dari hal-hal yang sudah mereka hargai, sehingga konsumen merasa terpuaskan dan akan melakukan kunjungan ulang (loyal).

Penulis fokus pada resort Kampung Sampireun karena berbeda dari resort yang lainnya lebih unik dan terkenal. Kampung Sampireun menyediakan jasa penginapan, restoran, pool dan spa yang bekerja sama dengan PT.Mustika Ratu tbk. Selain itu Kampung Sampireun juga menawarkan paketpaket wisata seperti halnya wisata kampung, one day tour, dan juga game-game bila mana ada permintaan. Hal ini dibuktikan dengan meningkatnya jumlah penjualan ruangan/kamar yang diperlihatkan pada Tabel 2.

Berdasarkan Tabel 2, penyewaan kamar Kampung Sampireun dari Tahun 2003 sampai 2007 terus mengalami peningkatan, Tahun 2003 dapat menyewakan kamar sebanyak 1,852. Tahun
2004 sebanyak 2,149, Kampung Sampireun dapat meningkatkan pelayanan sehingga penyewaan kamar bertambah sebanyak 638 kamar yaitu sebanyak 2,787 kamar. Tahun 2006 jumlah kamar yang tersewa sebanyak 3,010 dan untuk 2007 dapat menyewakan kamar sebanyak 3,538 kamar. Hal ini merupakan suatu keberhasilan dari resort Kampung Sampireun dalam rangka mempertahankan pelanggan (retensi), sehingga pengunjung yang datang merasakan pengalaman yang tidak akan terlupakan, karena sebagian besar tamu yang datang adalah tamu yang pernah berkunjung.

Tabel 2

Occopancy Rate tahun 2003-2007

\begin{tabular}{|l|c|c|c|c|c|}
\hline \multirow{2}{*}{ Month } & \multicolumn{5}{|c|}{ Room Sold } \\
\cline { 2 - 6 } & $\mathbf{2 0 0 3}$ & $\mathbf{2 0 0 4}$ & $\mathbf{2 0 0 5}$ & $\mathbf{2 0 0 6}$ & $\mathbf{2 0 0 7}$ \\
\hline Jan & 67 & 201 & 187 & 274 & 275 \\
\hline Feb & 59 & 126 & 132 & 161 & 142 \\
\hline Mar & 81 & 137 & 128 & 183 & 216 \\
\hline April & 116 & 86 & 156 & 207 & 223 \\
\hline May & 188 & 173 & 201 & 241 & 292 \\
\hline June & 199 & 195 & 235 & 250 & 338 \\
\hline July & 265 & 251 & 354 & 389 & 420 \\
\hline August & 156 & 187 & 291 & 293 & 367 \\
\hline Sept & 177 & 207 & 276 & 224 & 214 \\
\hline Okt & 178 & 133 & 156 & 204 & 313 \\
\hline Nov & 152 & 214 & 318 & 237 & 299 \\
\hline Dec & 214 & 239 & 353 & 347 & 439 \\
\hline Total & $\mathbf{1 , 8 5 2}$ & $\mathbf{2 , 1 4 9}$ & $\mathbf{2 , 7 8 7}$ & $\mathbf{3 , 0 1 0}$ & 3,538 \\
\hline
\end{tabular}

Sumber Data : Kampung Sampireun Garut, 2008

Berikut akan diperlihatkan data mengenai kisaran penyewaan kamar dari Tahun 2003-2007 yang diperlihatkan dalam Tabel di bawah ini

Tabel 3

Kisaran Penyewaan Kamar tahun 2003-2007

\begin{tabular}{|l|c|c|c|c|c|}
\hline \multirow{2}{*}{ Month } & \multicolumn{5}{|c|}{ Average Room Rate Tabel } \\
\cline { 2 - 6 } & $\mathbf{2 0 0 3}$ & $\mathbf{2 0 0 4}$ & $\mathbf{2 0 0 5}$ & $\mathbf{2 0 0 6}$ & $\mathbf{2 0 0 7}$ \\
\hline Jan & 705.541 & 666.786 & 746.774 & 904.355 & 877.992 \\
\hline Feb & 537.571 & 588.033 & 698.667 & 783.723 & 817.015 \\
\hline Mar & 556.589 & 663.085 & 747.716 & 803.511 & 803.913 \\
\hline April & 526.021 & 673.390 & 719.965 & 863.928 & 854.525 \\
\hline May & 556,437 & 672.694 & 701.346 & 773.636 & 895.689 \\
\hline June & 575.883 & 686.372 & 771.635 & 867.734 & 982.220 \\
\hline July & 608.407 & 650.089 & 763.945 & $92-.778$ & 969.934 \\
\hline August & 644.388 & 663.186 & 711.864 & 824.251 & 835.632 \\
\hline Sept & 588.089 & 643.760 & 667.343 & 810308 & 825.818 \\
\hline Okt & 539.075 & 648.543 & 765.844 & 1.110 .084 & 1.189 .192 \\
\hline Nov & 887.893 & 814.606 & 840.220 & 803.881 & 860.851 \\
\hline Dec & 816.797 & 884.807 & 899.257 & 1.093 .279 & 1.164 .225 \\
\hline Total & $\mathbf{7 . 5 4 2 . 6 9 1}$ & $\mathbf{8 . 2 5 5 . 3 5 1}$ & $\mathbf{9 . 0 3 4 . 5 7 6}$ & $\mathbf{1 0 . 5 5 9 . 4 6 8}$ & $\mathbf{1 1 . 0 7 7 . 0 6 6}$ \\
\hline
\end{tabular}

Sumber Data : Kampung Sampireun Garut, 2008

Berdasarkan Tabel 1.4 di atas rata-rata harga kamar per hari yang telah tersewa dari tahun 2003 sampai dengan tahun 2007 terus mengalami peningkatan, dan peningkatan yang terjadi hampir 41\%. Tahun 2003 pendapatan yang diperoleh sebesar Rp7.542.691, Tahun 2004 meningkat menjadi Rp 8.255.351 (9,45\%), kemudian Tahun 2005 naik lagi menjadi $9.034 .576(9,45 \%)$, Tahun 
2006 meningkat menjadi Rp 10.559 .468 (16,88\%), dan untuk Tahun 2007 meningkat lagi menjadi Rp 11.077 .066 (4,9\%).

Kampung Sampireun terdiri dari beberapa segmen pasar yang di dalamnya terdapat FIT, Travel, Group/Corporate, Walk in Guest, Honeymoon, dan Others. Berikut ini akan diperlihatkan dalam bentuk Tabel 1.5 data mengenai segmentasi pasar dari bulan JanuariDesember Tahun 2007.

Peningkatan yang terjadi di resort Kampung Sampireun tidak terlepas dari kinerja para karyawan yang dapat memuaskan pelanggan sehingga pelanggan melakukan penginapan lebih dari satu kali. Adapun data persentase perbandingan kenaikan pendapatan satu tahun sebelumnya pada Tabel 4 di bawah ini.

Tabel 4

Persentase Perbandingan Kenaikan Pendapatan (Tahun 2005-2007)

\begin{tabular}{|l|l|l|l|}
\hline Revenue & \multicolumn{1}{|c|}{$\mathbf{2 0 0 5}$} & \multicolumn{1}{|c|}{$\mathbf{2 0 0 6}$} & \multicolumn{1}{|c|}{$\mathbf{2 0 0 7}$} \\
\hline Room Available & 5106 & 5662 & 6546 \\
\hline Room sold & 2784 & 3010 & 3538 \\
\hline Occupancy & $55 \%$ & $53 \%$ & $54 \%$ \\
\hline Room & $21.88 \%$ & $24.88 \%$ & $28.48 \%$ \\
\hline F\&B & $14.30 \%$ & $19.30 \%$ & $27.20 \%$ \\
\hline SPA & $32.45 \%$ & $35.40 \%$ & $2.47 \%$ \\
\hline Tour & $29.63 \%$ & $148.11 \%$ & $51.17 \%$ \\
\hline Other & $12.56 \%$ & $37.70 \%$ & $25.88 \%$ \\
\hline Kenaikan Rata-rata & $23.15 \%$ & $25.91 \%$ & $27.52 \%$ \\
\hline
\end{tabular}

Sumber Data : Kampung Sampireun Garut, 2008

Berdasarkan Tabel di atas bahwa untuk persentase perbandingan kenaikan pendapatan satu Tahun sebelumnya dari tahun 2005 sampai dengan Tahun 2007 meningkat. Tahun 2005 dari kamar yang tersedia berjumlah 5106 meningkat pada Tahun 2006 menjadi 5662 kamar, dan untuk Tahun 2007 mengalami peningkatan lagi menjadi 6546 kamar. Hal ini dilakukan sebagai perbaikan dengan menambah fasilitas yang sudah ada, untuk penyewaan/kamar yang sudah habis terjual juga mengalami peningkatan tahun 2005 kamar yang tersewa sebanyak 2784 kamar, tahun 2006 naik menjadi 3010 kamar dan untuk tahun 2007 meningkat lagi menjadi 3538.

Berdasarkan data tersebut diperoleh rata-rata pendapatan yang mengalami fluktuatif, meningkatnya penyewaan kamar sesuai juga dengan penambahan kamar yang tersedia. Tahun 2005 rata-rata pendapatan sebesar 55\%, Tahun 2006 mengalami penurunan menjadi 53\% dan untuk Tahun 2007 mengalami kenaikan lagi sebesar $54 \%$. Sedangkan untuk kamar dan restoran terus mengalami peningkatan, karena Kampung Sampireun menjadi tempat favorit bagi mereka yang mau menginap dan untuk meluangkan akhir pekan bagi pengunjung yang membutuhkan istirahat dari rutinitas sehari-hari di kota besar.

Pada industri jasa seperti resort penciptaan memorable experience (pengalaman yang tidak terlupakan) lebih mudah diterapkan salah satunya dengan pendekatan pemasaran eksperiensial yang mengemas emosi secara komersil untuk setiap produk dan jasa, sehingga menarik pangsa pasar, karena yang dijual oleh perusahaan bukan hanya produk/jasa melainkan harus ada pengalaman yang tidak terlupakan oleh konsumen strategi semacam ini dikenal dengan Pemasaran Eksperiensial.

Pemasaran Eksperiensial begitu penting dilakukan perusahaan, karena dinilai dapat memberikan peluang bagi perusahaan sebagai bentuk diferensiasi, terlebih lagi jika pemasaran eksperiensial yang diterapkan dengan sungguhsungguh dengan konsep yang jelas dan kerap digunakan untuk meningkatkan retensi pelanggan.

Apabila perusahaan memberikan suatu pengalaman manis pada konsumen maka akan banyak dampak positif bagi perusahaan, dengan adanya hal tersebut konsumen dapat melakukan keputusan tidak akan memandang cost dan benefit namun mereka mempertimbangkan nilai emosi dari merek/perusahaan.

Kampung Sampireun akan berusaha agar mereka yang menginap di resort ini akan mendapatkan pengalaman terindah yang tidak terlupakan, sehingga retensi pelanggan akan tetap terpelihara dan meningkat.

Berdasarkan latar belakang tersebut, maka penelitian ini dirumuskan kedalam rumusan masalah sebagai berikut:
1. Bagaimana gambaran Pemasaran Eksperiensial di Resort\&Spa Kampung Sampireun.

2. Bagaimana gambaran Retensi Pelanggan di Resort\&Spa Kampung Sampireun.

3. Seberapa besar pengaruh Pemasaran Eksperiensial terhadap Retensi Pelanggan di Resort\&Spa Kampung Sampireun.

\section{KERANGKA PEMIKIRAN}

Pemasaran merupakan kegiatan yang sangat penting meliputi kegiatan sebelum dan sesudah 
penjualan. Kegiatan pemasaran dimulai dari mendesain konsep produk baru, menganalisis pasar, dan mengembangkan konsep produk tersebut sesuai dengan kebutuhan dan keinginan konsumen yang belum terpenuhi.

Menurut Kotler dan Amstrong (2006:9), pemasaran adalah suatu proses sosial yang didalamnya individu dan kelompok mendapat apa yang mereka butuhkan dan inginkan dengan menciptakan, menawarkan, dan secara bebas mempertukarkan produk yang bernilai dengan pihak lain.

Konsep paling dasar yang melandasi pemasaran adalah kebutuhan manusia. Kebutuhan (needs) manusia adalah pernyataan dari perasaan kekurangan. Kebutuhan meliputi kebutuhan fisik dasar akan makanan, pakaian, kehangatan dan rasa aman. Kebutuhan sosial akan rasa memiliki dan kasih sayang serta kebutuhan individual akan pengetahuan dan ekspresi diri. Kebutuhan ini tidak diciptakan oleh pemasar, mereka merupakan bagian mendasar dari diri manusia. Keinginan (wants) adalah kebutuhan yang dibentuk oleh budaya dan kepribadian seseorang. Manusia memiliki sumber daya yang terbatas, jadi mereka memilih produk yang memberi nilai dan kepuasan terbesar dari uang mereka.

Menurut Hermawan Kertajaya dalam Buchari Alma (2005:3) Pemasaran adalah "Sebuah disiplin bisnis strategis yang mengarahkan proses penciptaan, penawaran, dan perubahan values dari suatu inisiator kepada stakeholders".

Hakikatnya tujuan pemasaran adalah memenuhi dan memuaskan kebutuhan dan keinginan manusia. Manusia memuaskan kebutuhan dan keinginan mereka dengan produk dan jasa, pelanggan biasanya menghadapi sederetan produk dan jasa yang dapat memuaskan kebutuhan tertentu.

Menurut Pine and Gilmore (1999:2) tingkat pemasaran dalam dunia bisnis saat ini adalah: "Commodities marketing, goods marketing, services marketing, experiential marketing, dan transformation marketing"

1. Commodities marketing. Dimana pada tingkatan ini tidak terdapat perbedaan antara suatu produk dengan produk lainnya, selain itu penentuan harga tidak bisa dilakukan sendiri karena sangat bergantung pada suplay dan demand.
2. Goods marketing. Pada tingkatan ini sudah memperlihatkan adanya suatu perbedaan atau diferensiasi antara produk kita dengan produk pesaing dan harga dapat ditentukan sendiri.

3. Service marketing. Tingkatan pemasaran ini telah memperhatikan kepuasan yang diperoleh konsumen, yaitu dengan memberikan pelayanan sebelum atau setelah penjualan.

4. Experiential marketing. Pada tahap pemasaran tujuannya bukan hanya untuk memuaskan konsumen tetapi untuk menarik hati konsumen dan memberikan suatu pengalaman dan memori yang mengesankan dan berumur panjang.

5. Transformation marketing. Pada tingkatan ini bukan hanya menciptakan memori jangka panjang, tetapi juga bisa melakukan transformasi secara lebih permanen.

Salah satu konsepnya dari pemasaran adalah pengalaman (experiential) merupakan hal yang penting dalam pemasaran. Pemasaran tingkat experiential merupakan bentuk pemasaran yang sesuai dengan kondisi saat ini, karena konsumen tidak lagi dipandang sebagai konsumen yang rasional namun konsumen yang emosional, yakni menggunakan emosi dalam menentukan produk.

Schmitt (1999:60) menjelaskan kerangka kerja konseptual dalam mengelola akumulasi pengalaman pelanggan (experiential marketing) bagi suatu perusahaan. Fokus kerangka kerja (frame work) tersebut dibagi menjadi dua konsep, yaitu strategic experiental modules (SEMs) yang merupakan pondasi experiential marketing dan experiential providers (ExPros) sebagai alat taktis untuk mengimplementasikan experiential marketing.

Menurut Schmitt (1999:60) dalam Experiential Marketing dalam mengukur SEMs terdiri dari lima tipe tahapan pengalaman yang menjadi bentuk dasar experiential marketing frame work, kelima tipe tersebut adalah:

1) Sense (Panca indra konsumen)

Sense adalah kelima indera yang dimiliki manusia sebagai alat untuk merasakan produk dan jasa yang ditawarkan. Sense yang ditawarkan oleh setiap produk harus distimulus dengan benar agar dapat memberikan sesuatu yang mengesankan. Jadi, sense marketing diartikan bagaimana menciptakan suatu pengalaman pada konsumen melalui sentuhan terhadap kelima indera. 
2) Feel (Perasaan konsumen)

Feel marketing ialah strategi dan implementasi dalam mengikat konsumen untuk senang terhadap pertunjukan dan merek melalui experience provider (pemberian pengalaman). Agar feel marketing berhasil maka kita harus mengetahui bagaimana menciptakan perasaan melalui pengalaman saat atau setelah menyaksikan pertunjukan.

\section{3) Think (Pemikiran konsumen)}

Think marketing campaign (pemasar yang kreatif) adalah model metode pemasaran yang mendorong pelanggan untuk berpikir kreatif atas perusahaan dan merek-mereknya. Pelanggan didorong untuk berpikir mengenai merek atau slogan yang digunakan perusahaan. Perusahaan tidak lagi menjelaskan mengenai featuress dan benefit dari merek-mereknya secara langsung melainkan mendorong agar pelanggan sendiri yang memikirkannya. Iklan-iklan perusahaan yang menggunakan think marketing campaign biasanya mempunyai sedikit kata-kata dan sedikit gambar tapi mempunyai kesan mendalam dan mendorong kita untuk berfikir apa sebenarnya maksud dan tujuan iklan itu.

4) Act (Aksi yang dilakukan konsumen)

Strategi act marketing dirancang untuk menciptakan pengalaman pelanggan yang dihubungkan pada perilaku individu, perilaku sosial, dan gaya hidup, seperti halnya pengalaman yang timbul melalui interaksi sosial. Dalam strategi ini produk bukan ditawarkan sebagai sesuatu yang memiliki fungsi atau manfaat. Dalam experiential marketing, produk harus dapat menciptakan pengalaman pada pelanggan.

5) Relate (Hubungan konsumen dan perusahaan)

Sebagai tipe terakhir dalam SEMs, relate merupakan hubungan atau gaya hidup yang dirasakan pelangggan, baik itu hubungan terhadap perusahaan maupun hubungan sesama komunitas pengguna produk atau jasa perusahaan. Relate marketing merupakan kombinasi sense, feel, dan think marketing yang bertujuan menghubungkan individu dengan sesuatu yang berada di luar dirinya.

Selain experiential marketing yang memiliki peranan penting dalam pemasaran adalah retensi pelanggan. Menurut Frederich Reicheld oleh Hermawan Kartajaya (2007:32)"Perusahaan lebih fokus pada upaya mempertahankan jumlah pelanggan yang hilang".
Menurut Schmitt (2002:214), "The customer interface affect retention because interface exchanges and interactions determine whether customer are satisfied wit their relationship with the company and whether they buy again. Thus, the customer interface is generally the most important determinant of retensi pelanggan" (Hubungan pelanggan dengan perusahaan mempengaruhi retensi pelanggan karena setiap interaksi menentukan apakah pelanggan merasa puas terhadap hubungan mereka dengan perusahaan tersebut dan apakah mereka akan membeli lagi di tempat tersebut. Jadi hubungan pelanggan dengan perusahaan sangat penting dalam mempengaruhi retensi pelanggan).

Menurut Odekerken (2003) dan Gruen (1995) Pengukuran Retensi pelanggan terbagi atas:

1) Trust (Kepercayaan)

Kepercayaan adalah keyakinan bahwa seseorang akan menemukan apa yang diinginkan pada mitra pertukaran. Kepercayaan melibatkan kesediaan seseorang untuk bertingkah laku tertentu karena keyakinan bahwa mitranya akan memberikan apa yang ia harapkan dan suatu harapan yang umumnya dimiliki seseorang bahwa kata, janji atau pernyataan orang lain dapat dipercaya (Barnes, 2003:148).

2) Satisfaction (Kepuasan)

Faktor kepuasan pelanggan bukan jaminan mutlak bahwa pelanggan pasti kembali. Tetapi menurut Philip Kotler, kunci dari keberhasilan retensi pelanggan adalah kepuasan pelanggan. Pelanggan yang puas adalah yang menunjukkan loyalitas pada periode waktu yang lama, yang mau merekomendasikan produk/jasa ke teman atau relasinya, yang tidak mudah tertarik tawaran perusahaan lain.

\section{3) Commitment (Komitmen)}

Loyalitas dan retensi pelanggan dapat timbul bila ada kepercayaan terhadap merek produk/jasa yang kuat. Rasa percaya ini makin lama akan membentuk komitmen yang kuat dan direfleksikan dengan komunikasi dan interaksi berkaitan dengan produk tersebut. Komitmen yang tinggi akan mendorong konsumen untuk membicarakan dan merekomendasikan kepada orang lain.

Berdasarkan penjelasan di atas jelas bahwa dalam proses mempertahankan pelanggan atau menjadikan konsumen menjadi konseumen yang setia pada perusaaan, pemasaran eksperiensial memegang peranan penting yang harus 
diperhatikan oleh pengusaha dalam mempengaruhi retensi pelanggan.

Berdasarkan kerangka pemikiran di atas, maka penulis memberikan paradigma penelitian sebagai berikut:

\begin{tabular}{|l|}
\hline \multicolumn{1}{|c|}{ Pemasaran } \\
Eksperiensial \\
1. Sense \\
2. Feel \\
3. Think \\
4. Act \\
5. Relate \\
(Schmitt, 1999:60)
\end{tabular}$\quad \longrightarrow \quad$\begin{tabular}{c} 
Retensi \\
Pelanggan \\
\\
1. Trust (Kepercayaan) \\
2. Satisfaction (Kepuasan) \\
3. Commitment (komitmen) \\
(Odokerken, 2003; \\
dan Gruen 1995) \\
\hline
\end{tabular}

Gambar 2

Paradigma Penelitian Pengaruh Pemasaran Eksperiensial terhadap retensi pelanggan

\section{METODE PENELITIAN}

Berdasarkan tingkat penjelasan dan bidang penelitian, maka jenis penelitian ini adalah penelitian deskriptif dan verifikatif. Menurut pendapat Sugiyono (2006:11), "Penelitian deskriptif adalah penelitian yang dilakukan untuk mengetahui nilai variabel mandiri, baik satu variabel atau lebih (independent) tanpa membuat perbandingan, atau menghubungkan antara variabel satu dengan variabel yang lain". Melalui jenis penelitian deskriptif maka dapat diperoleh deskripsi mengenai gambaran pemasaran eksperiensial pada resort\&spa Kam-pung Sampireu; gambaran retensi pelanggan pada resort\&spa Kampung Sampireun.

\section{StrategiC}

Penelitian verifikatif pada dasarnya ingin menguji kebenaran pengumpulan data di lapangan (Suharsimi Arikunto, 2006:8). Peneli-tian verifikatif bertujuan untuk mengetahui pengaruh pemasaran eksperiensial terhadap retensi pelanggan.

Berdasarkan jenis penelitiannya, yaitu penelitian deskriptif dan verifikatif, maka metode yang digunakan dalam penelitian ini adalah survey explanatory. Menurut Kerlinger, yang dimaksud dengan metode survey adalah metode penelitian yang dilakukan pada populasi besar maupun kecil, tetapi data yang dipelajari adalah data dari sampel yang diambil dari populasi tersebut, sehingga ditemukan kejadian-kejadian relatif, distribusi, dan hubungan-hubungan antar variabel sosiologis maupun psikologis.

Penelitian yang menggunakan metode ini, informasi dari sebagian populasi dikumpulkan langsung ditempat kejadian secara empirik dengan tujuan untuk mengetahui pendapat dari sebagian populasi terhadap objek yang sedang diteliti. Selain itu, dikarenakan penilitian ini dilakukan pada kurun waktu kurang dari satu tahun yakni di mulai dari bulan Februari 2008 sampai dengan bulan Juni 2008, maka metode pengembangan yang digunakan adalah cross sectional.

Menurut Husein Umar (2002:45) "Metode cross sectional adalah metode penelitian dengan cara mempelajari objek dalam kurun waktu tertentu".

Tabel 5

Operasionalisasi Variabel Penelitian

\begin{tabular}{|c|c|c|c|c|c|}
\hline Variabel & Sub variabel & Konsep variabel & Indikator & Ukuran & Skala \\
\hline $\begin{array}{l}\text { Pemasaran } \\
\text { Eksperien- } \\
\text { sial } \\
\text { (X) }\end{array}$ & & $\begin{array}{l}\text { Konsep pemasaran dari } \\
\text { kemampuan suatu produk } \\
\text { dalam Menawarkan } \\
\text { pengalaman emosi hingga } \\
\text { menyentuh hati dan perasaan } \\
\text { konsumen } \\
\text { (Schmitt,1999:22) }\end{array}$ & & & \\
\hline & \multirow[t]{5}{*}{$\begin{array}{l}\text { Sense/ } \\
\text { Panca } \\
\text { Indera }\end{array}$} & \multirow[t]{5}{*}{$\begin{array}{l}\text { Alat untuk merasakan produk } \\
\text { dan jasa yang ditawarkan } \\
\text { (Schmitt,1999:64) }\end{array}$} & Penglihatan & $\begin{array}{l}\text { Tingkat penglihatan pada } \\
\text { dekorasi tata ruang kampung } \\
\text { sampireun }\end{array}$ & Ordinal \\
\hline & & & Pendengaran & $\begin{array}{l}\text { Tingkat pendengaran pada } \\
\text { hiburan musik tradisional di } \\
\text { kampung sampireun }\end{array}$ & Ordinal \\
\hline & & & Peraba & $\begin{array}{l}\text { Tingkat peraba pada } \\
\text { peralatan di kampung } \\
\text { sampireun }\end{array}$ & Ordinal \\
\hline & & & Penciuman & $\begin{array}{l}\text { Tingkat penciuman pada } \\
\text { menu yang disajikan } \\
\text { kampung sampireun }\end{array}$ & Ordinal \\
\hline & & & Perasa & $\begin{array}{l}\text { Tingkat perasa pada kondisi } \\
\text { atau tempat di kampung }\end{array}$ & Ordinal \\
\hline
\end{tabular}

Pengaruh Pemasaran Eksperensial terhadap Retensi Pelanggan pada Pengunjung Resort\&Spa Kampung Sampireun Garut 


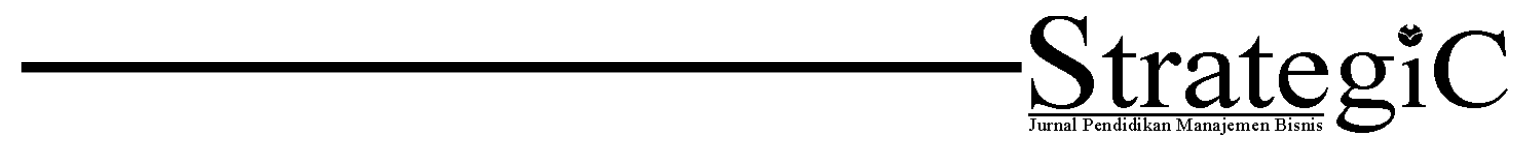

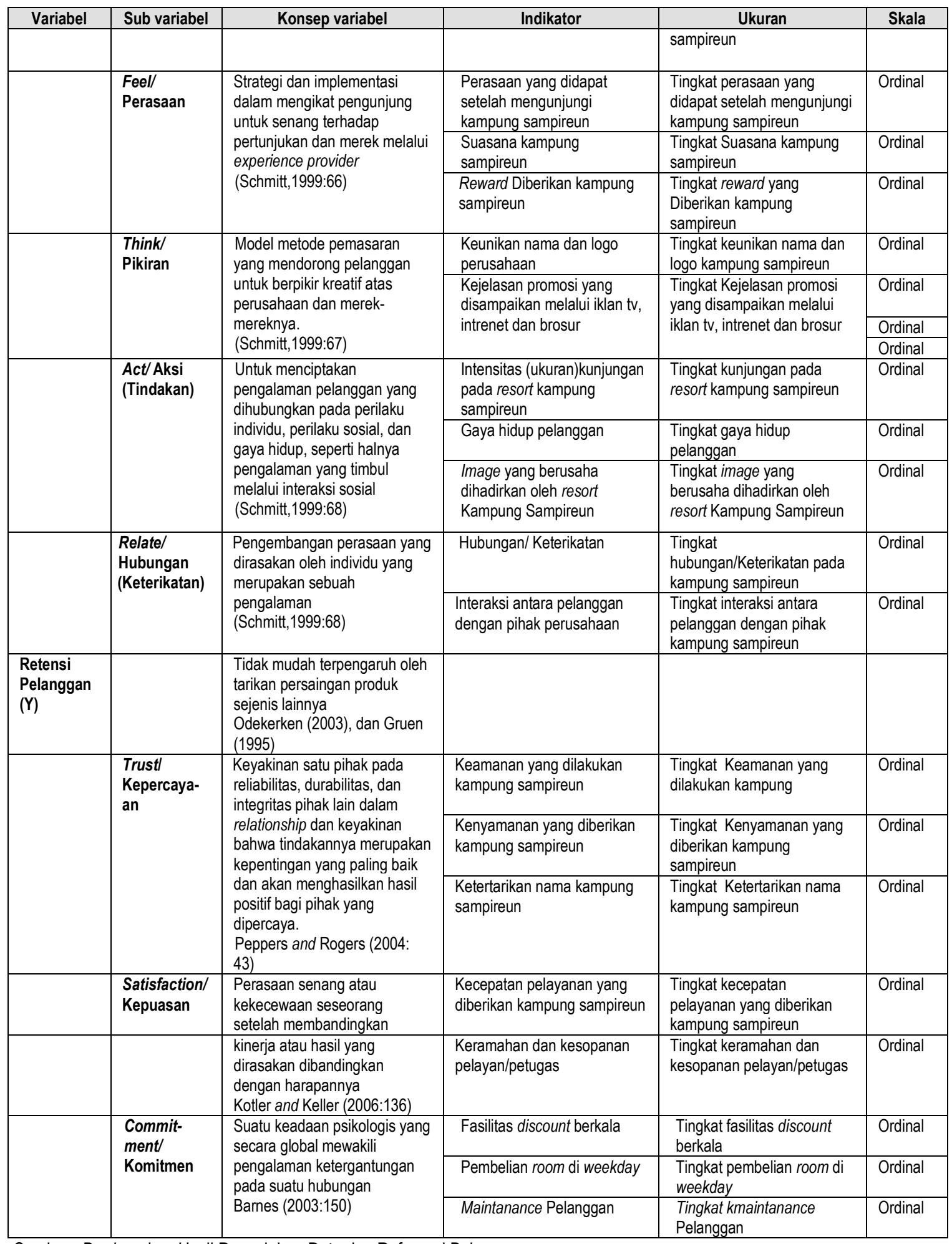

Sumber : Berdasarkan Hasil Pengolahan Data dan Referensi Buku 


\section{StrategiC}

DESKRIPSI VARIABEL PENELITIAN BERDASARKAN SURVEI

\section{Tanggapan Responden Terhadap \\ Pemasaran Eksperiensial Resort\&Spa \\ Kampung sampireun}

Variabel-variabel yang diteliti pada penelitian ini adalah pemasaran eksperiensial sebagai variabel $X$ yang terdiri dari sense, feel, think, act, dan relate serta retensi pelanggan sebagai variabel Y yang terdiri dari trust, satisfaction, dan commitment.

Penelitian ini dilakukan untuk meneliti mengenai tanggapan responden yang terdiri dari 60 responden. Tanggapan responden mengenai variabel-variabel tersebut melalui penyebaran kuesioner, berikut ini disajkan variasi skor tanggapan untuk masing-masing variabel.

1. Tanggapan Responden Terhadap Sense Resort\&Spa Kampung Sampireun

a. Tanggapan Responden Terhadap Dekorasi Tata Ruang

Berdasarkan data yang diperoleh dari penyebaran kuesioner terhadap 60 responden, maka akan dapat diketahui sejauh mana responden merasakan pengalaman yang tercipta setelah mengunjungi resort\&spa Kampung Sampireun. Pengalaman yang dirasakan yakni mengenai hal yang paling menarik bagi responden saat mengunjungi resort\&spa Kampung Sampireun.

Tabel 6

Tanggapan Responden terhadap Dekorasi Tata Ruang Resort\&Spa Kampung Sampireun

\begin{tabular}{|l|l|c|c|c|}
\hline Pernyataan & $\begin{array}{c}\text { Alternatif } \\
\text { Jawaban }\end{array}$ & $\mathbf{F}$ & $\mathbf{\%}$ & Skor \\
\hline \multirow{2}{*}{$\begin{array}{l}\text { Dekorasi tata } \\
\text { ruang } \\
\text { resort\&spa }\end{array}$} & Sangat Menarik & 10 & 16,7 & 50 \\
\cline { 2 - 5 } $\begin{array}{l}\text { Kampung } \\
\text { Sampireun }\end{array}$ & Menarik & 39 & 65,0 & 156 \\
\cline { 2 - 5 } & Ragu-Ragu & 11 & 18,3 & 33 \\
\cline { 2 - 5 } & $\begin{array}{l}\text { Sidak Menarik } \\
\text { Menarik }\end{array}$ & 1 & 1,7 & 2 \\
\hline \multicolumn{2}{|c|}{ Total } & $\mathbf{6 0}$ & $\mathbf{1 0 0}$ & $\mathbf{2 3 9}$ \\
\hline
\end{tabular}

Sumber: Hasil Pengolahan Data 2008

Berdasarkan Tabel 6 di atas dapat diperoleh gambaran tanggapan responden mengenai dekorasi tata ruang resort\&spa Kampung Sampireun memperoleh skor sebesar 239 yang terdiri dari sebagian besar yaitu 39 responden $(65,0 \%)$ menyatakan menarik, hampir setenghnya yaitu 10 responden $(16,7 \%)$ menyatakan sangat menarik pada dekorasi tata ruang resort\&spa Kampung Sampireun. Dekorasi tata ruang dibuat sedemikian unik sehingga pengunjung merasakan suasana lain, hampir setenghnya11 responden $(18,3 \%)$ menyatakan ragu-ragu dan sebagian kecil yaitu 1 responden $(1,7 \%)$ menyatakan tidak menarik pada dekorasi tata ruang resort\&spa Kampung Sampireun.

Berdasarkan pernyataan responden tersebut dapat diketahui bahwa hampir seluruhnya yaitu $90,85 \%\{(16,7+65,0+(18,3: 2)\}$ dari 60 responden menyatakan bahwa dekorasi tata ruang pada resort\&spa Kampung Sampireun sudah menarik.

b. Tanggapan Responden Terhadap Penyelenggaraan Musik Tradisional

Berdasarkan hasil pengolahan data yang diambil dari jawaban pertanyaan-pertanyaan dalam angket yang diberikan kepada 60 responden, maka dapat diperoleh hasil mengenai tanggapan responden terhadap penyelenggaraan musik disajikan pada Tabel 7 berikut.

Tabel 7

Tanggapan Responden terhadap Penyelenggaraan Musik Tradisional di Resort\&Spa Kampung Sampireun

\begin{tabular}{|l|l|c|c|c|}
\hline Pernyataan & $\begin{array}{c}\text { Alternatif } \\
\text { Jawaban }\end{array}$ & $\mathbf{F}$ & $\%$ & Skor \\
\hline $\begin{array}{l}\text { Penyelengga } \\
\text { raan musik } \\
\text { tradisional di }\end{array}$ & Sangat Menarik & 14 & 23,3 & 70 \\
\cline { 2 - 5 } $\begin{array}{l}\text { resort\&spa } \\
\text { Kampung } \\
\text { Sampireun }\end{array}$ & Menarik & 33 & 55,0 & 132 \\
\cline { 2 - 5 } & Ragu-Ragu & 13 & 21,7 & 39 \\
\cline { 2 - 5 } & $\begin{array}{l}\text { Sidak Menarik } \\
\text { Menarik }\end{array}$ & 0 & 0 & 0 \\
\hline \multicolumn{2}{|l}{ Total } & $\mathbf{6 0}$ & $\mathbf{1 0 0}$ & $\mathbf{2 4 1}$ \\
\hline
\end{tabular}

Sumber: Hasil Pengolahan Data 2008

Berdasarkan Tabel 4.9 di atas dapat diperoleh gambaran tanggapan responden mengenai penyelenggaraan musik tradisional di resort\&spa Kampung Sampireun memperoleh skor sebesar 241 yang terdiri dari sebagian besar yaitu 33 responden $(65,0 \%)$ meyatakan menarik, hampir setenghnya yaitu 14 responden $(23,3 \%)$ menyatakan sangat menarik terhadap penyelenggaraan musik tradisional di resort\&spa Kampung Sampireun. Musik tradisional ini disesuaikan dengan konsep resort sendiri yang bertemakan suasana pedesaan supaya pengunjung merasa nyaman, dan hampir setenghnya yaitu 13 responden $(21,7 \%)$ menyatakan ragu-ragu.

Berdasarkan pernyataan responden tersebut dapat diketahui bahwa hampir seluruhnya yaitu $89,15 \%\{(23,3+55,0+(21,7: 2)\}$ dari 60 responden menyatakan bahwa penyelenggaraan musik 


\section{StrategiC}

tradisional di resort\&spa Kampung Sampireun sudah menarik.

\section{c. Tanggapan Responden Terhadap Lokasi atau Tempat}

Berdasarkan hasil pengolahan data yang diambil dari jawaban pertanyaan-pertanyaan dalam angket yang diberikan kepada 60 responden, maka dapat diperoleh hasil mengenai tanggapan responden terhadap lokasi atau tempat resort\&Spa Kampung Sampireun disajikan pada Tabel 8 berikut.

Tabel 8

Tanggapan Responden terhadap Lokasi atau Tempat Resort\&Spa Kampung Sampireun

\begin{tabular}{|c|c|c|c|c|}
\hline Pernyataan & $\begin{array}{l}\text { Alternatif } \\
\text { Jawaban }\end{array}$ & $F$ & $\%$ & Skor \\
\hline \multirow{5}{*}{$\begin{array}{l}\text { Lokasi atau } \\
\text { Tempat } \\
\text { resort\&spa } \\
\text { Kampung } \\
\text { Sampireun }\end{array}$} & Sangat Menarik & 24 & 40,0 & 120 \\
\hline & Menarik & 32 & 53,3 & 128 \\
\hline & Ragu-Ragu & 4 & 6,7 & 12 \\
\hline & Tidak Menarik & 0 & 0 & 0 \\
\hline & $\begin{array}{l}\text { Sangat Tidak } \\
\text { Menarik }\end{array}$ & 0 & 0 & 0 \\
\hline \multicolumn{2}{|c|}{ Total } & 60 & 100 & 260 \\
\hline
\end{tabular}

Sumber: Hasil Pengolahan Data 2008

Berdasarkan Tabel 4.10 di atas dapat diperoleh gambaran tanggapan responden mengenai lokasi atau tempat resort\&spa Kampung Sampireun memperoleh skor sebesar 260 yang terdiri dari sebagian besar yaitu 32 responden (53,3\%) menyatakan menarik, hampir setenghnya yaitu 24 responden $(40,0 \%)$ menyatakan sangat menarik pada lokasi atau tempat resort\&spa Kampung Sampireun. Lokasi atau tempat dibuat jauh dari keramaian dan yang mempunyai udara sejuk supaya pengunjung tidak terganggu dan merasa nyaman. Sebagian kecil yaitu 4 responden $(6,7 \%)$ menyatakan ragu-ragu pada lokasi atau tempat resort\&spa Kampung Sampireun.

Berdasarkan pernyataan responden tersebut dapat diketahui bahwa hampir seluruhnya yaitu $96,65 \%\{(40,0+53,3+(6,7: 2)\}$ dari 60 responden menyatakan bahwa lokasi atau temapt resort\&spa Kampung Sampireun sudah menarik.

\section{d. Tanggapan Responden Terhadap Menu yang Disajikan}

Berdasarkan hasil pengolahan data yang diambil dari jawaban pertanyaan-pertanyaan dalam angket yang diberikan kepada 60 responden, maka dapat diperoleh hasil mengenai tanggapan responden terhadap menu yang disajikan pada Tabel 9 berikut.
Tabel 9

Tanggapan Responden terhadap Menu yang Disajikan di Resort\&Spa Kampung Sampireun

\begin{tabular}{|c|c|c|c|c|}
\hline Pernyataan & $\begin{array}{l}\text { Alternatif } \\
\text { Jawaban }\end{array}$ & $F$ & $\%$ & Skor \\
\hline \multirow{5}{*}{$\begin{array}{l}\text { Menu yang } \\
\text { disaijikan } \\
\text { resort\&spa } \\
\text { Kampung } \\
\text { Sampireun }\end{array}$} & Sangat Enak & 15 & 25,0 & 75 \\
\hline & Enak & 30 & 50,0 & 120 \\
\hline & Ragu-Ragu & 15 & 25,0 & 45 \\
\hline & Tidak Enak & 0 & 0 & 0 \\
\hline & $\begin{array}{l}\text { Sangat Tidak } \\
\text { Enak }\end{array}$ & 0 & 0 & 0 \\
\hline \multicolumn{2}{|c|}{ Total } & 60 & 100 & 240 \\
\hline
\end{tabular}

Sumber: Hasil Pengolahan Data 2008

Berdasarkan Tabel 4.11 di atas dapat diperoleh gambaran tanggapan responden mengenai menu yang disajikan resort\&spa Kampung Sampireun memperoleh skor 240 yang terdiri dari setenghnya yaitu 30 responden $(50,0 \%)$ menyatakan enak, hampir setenghnya yaitu 15 responden $(25,0 \%)$ menyatakan sangat enak pada menu yang disajikan, hampir setenghnya yaitu 15 responden $(25,0 \%)$ menyatakan ragu-ragu dan tidak ada satu orang pun dari responden yang menyatakan tidak enak.

Berdasarkan pernyataan responden tersebut dapat diketahui bahwa hampir seluruhnya yaitu $87,5 \%\{(25,0+50,0+(25,0: 2)\}$ dari 60 responden menyatakan bahwa menu yang disajikan oleh resort\&spa Kampung Sampireun sudah enak.

\section{e. Tanggapan Responden Terhadap Kondisi \\ Peralatan}

Berdasarkan hasil pengolahan data yang diambil dari jawaban pertanyaan-pertanyaan dalam angket yang diberikan kepada 60 responden, maka dapat diperoleh hasil mengenai tanggapan responden terhadap kelayakan kondisi peralatan resort\&Spa Kampung Sampireun disajikan pada Tabel 10 berikut.

Tabel 10

Tanggapan Responden terhadap Kondisi Peralatan di Resort\&Spa Kampung Sampireun

\begin{tabular}{|l|l|c|c|c|}
\hline Pernyataan & $\begin{array}{c}\text { Alternatif } \\
\text { Jawaban }\end{array}$ & $\mathbf{F}$ & $\%$ & Skor \\
\hline $\begin{array}{l}\text { Kelayakan } \\
\text { kondisi } \\
\text { peralatan di } \\
\text { resort\&spa }\end{array}$ & Sangat Layak & 17 & 28,3 & 85 \\
\cline { 2 - 5 } $\begin{array}{l}\text { Kampung } \\
\text { Sampireun }\end{array}$ & Layak & 27 & 45,0 & 108 \\
\cline { 2 - 5 } & Ragu-Ragu & 15 & 26,7 & 45 \\
\cline { 2 - 5 } & $\begin{array}{l}\text { Sangat Tidak } \\
\text { Layak }\end{array}$ & 0 & 0 & 0 \\
\hline \multicolumn{2}{|c|}{ Total } & $\mathbf{6 0}$ & $\mathbf{1 0 0}$ & $\mathbf{2 4 0}$ \\
\hline
\end{tabular}

Sumber: Hasil Pengolahan Data 2008 
Berdasarkan Tabel 10 di atas dapat diperoleh gambaran tanggapan responden mengenai kelayakan kondisi peralatan di resort\&spa Kampung Sampireun memperoleh skor sebesar 248 yang terdiri dari hampir setenghnya yaitu 27 responden $(45,0 \%)$ menyatakan layak, 17 responden $(28,3 \%)$ menyatakan sangat layak. Peralatan di Kampung Sampireun sangat unik dan menarik disesuaikan dengan konsep yang diadopsi yaitu etnik tradisional Sunda. Hampir setenghnya yaitu 15 responden $(26,7 \%)$ menyatakan raguragu, 1 responden (1,7\%) yang menyatakan tidak layak.

Berdasarkan pernyataan responden tersebut dapat diketahui bahwa hampir seluruhnya yaitu $86,65 \%\{(28,3+45,0+(26,7: 2)\}$ dari 60 responden menyatakan bahwa peralatan di resort\&spa Kampung Sampireun sudah layak.

Berdasarkan skor yang diperoleh paling tinggi dari kelima pertanyaan adalah pada lokasi atau tempat resort\&spa Kampung Sampireun dengan skor 260. Hal ini membuktikan bahwa lokasi atau tempat resort\&spa Kampung Sampireun banyak disukai karena jauh dari keramaian dan kebisingan juga udaranya yang sejuk membuat pengunjung tidak terganggu dan merasa nyaman.

Sedangkan dekorasi pada tata ruang memiliki nilai terendah dengan skor 239, maka pihak resort\&spa Kampung Sampireun harus lebih meningkatkan kreatifitas dalam design bangunan yang membedakan dengan resort-resort lain sehingga Kampung Sampireun tetap bertahan sebagai resort yang paling unik dan menarik.

\section{Tanggapan Responden Terhadap Feel Resort\&Spa Kampung Sampireun}

a. Tanggapan Responden Terhadap Perasaan (Mood) Setelah Berkunjung

Tabel 11

Tanggapan Responden terhadap Perasaan Setelah

Berkunjung ke Resort\&Spa Kampung Sampireun

\begin{tabular}{|c|c|c|c|c|}
\hline Pernyataan & $\begin{array}{l}\text { Alternatif } \\
\text { Jawaban }\end{array}$ & $\mathbf{F}$ & $\%$ & Skor \\
\hline \multirow{5}{*}{$\begin{array}{l}\text { Perasaan } \\
\text { yang didapat } \\
\text { setelah } \\
\text { mengunjungi } \\
\text { resort\&spa } \\
\text { Kampung } \\
\text { Sampireun }\end{array}$} & Sangat Puas & 15 & 25,0 & 75 \\
\hline & Puas & 28 & 46,7 & 112 \\
\hline & Ragu-Ragu & 16 & 28,3 & 48 \\
\hline & Tidak Puas & 1 & 1,7 & 2 \\
\hline & $\begin{array}{l}\text { Sangat Tidak } \\
\text { Puas }\end{array}$ & 0 & 0 & 0 \\
\hline \multicolumn{2}{|c|}{ Total } & 60 & 100 & 235 \\
\hline
\end{tabular}

Sumber: Hasil Pengolahan Data 2008
Berdasarkan Tabel 4.13 di atas dapat diperoleh gambaran tanggapan responden mengenai perasaan (Mood) yang didapat setelah mengunjungi resort\&spa Kampung Sampireun memperoleh skor sebesar 235 yang terdiri dari hampir setenghnya yaitu 28 responden $(46,7 \%)$ menyatakan puas, 15 responden $(25,0 \%)$ menyatakan sangat puas. Kampung Sampireun sangat memperhatikan kebutuhan dan kenyamanan pengunjung sehingga tamu yang berkunjung merasa puas, hampir setenghnya yaitu $16(28,3 \%)$ menyatakan ragu-ragu, dan sebagian kecil yaitu $1(1,7 \%)$ menyatakan tidak puas.

Berdasarkan pernyataan responden tersebut dapat diketahui bahwa hampir seluruhnya yaitu $85,85 \%\{(25,0+46,7+(28,3: 2)\}$ dari 60 responden menyatakan bahwa perasaan setelah berkunjung ke resort\&spa Kampung Sampireun sudah puas.

\section{b. Tanggapan Responden Terhadap Suasana}

Berdasarkan hasil pengolahan data yang diambil dari jawaban pertanyaan-pertanyaan dalam angket yang diberikan kepada 60 responden, maka dapat diperoleh hasil mengenai tanggapan responden terhadap suasana resort \& Spa Kampung Sampireun disajikan pada Tabel 12 berikut.

Tabel

Tanggapan Responden terhadap Suasana di Resort\&Spa Kampung Sampireun

\begin{tabular}{|l|l|c|c|c|}
\hline Pernyataan & $\begin{array}{c}\text { Alternatif } \\
\text { Jawaban }\end{array}$ & $\mathbf{F}$ & $\mathbf{\%}$ & Skor \\
\hline \multirow{3}{*}{$\begin{array}{l}\text { Suasana } \\
\text { resort\&spa } \\
\text { Kampung } \\
\text { Sampireun }\end{array}$} & Sangat Nyaman & 23 & 38,3 & 85 \\
\cline { 2 - 5 } & Nyaman & 33 & 55,0 & 108 \\
\cline { 2 - 5 } & Ragu-Ragu & 4 & 6,7 & 45 \\
\cline { 2 - 5 } & Tidak Nyaman & 0 & 0 & 2 \\
\cline { 2 - 5 } & $\begin{array}{l}\text { Sangat Tidak } \\
\text { Nyaman }\end{array}$ & 0 & 0 & 0 \\
\hline \multicolumn{2}{|l|}{ Total } & $\mathbf{6 0}$ & $\mathbf{1 0 0}$ & $\mathbf{2 5 9}$ \\
\hline
\end{tabular}

Sumber: Hasil Pengolahan Data 2008

Berdasarkan Tabel 4.14 di atas dapat diperoleh gambaran tanggapan responden mengenai suasana resort\&spa Kampung Sampireun memperoleh skor sebesar 259 yang terdiri dari sebagian besar yaitu 33 responden $(55,0 \%)$ menyatakan nyaman, 23 responden $(38,3, \%)$ menyatakan sangat nyaman. Kampung Sampireun merupakan resort yang unik dan menarik dengan bungalow di atas danau sehingga pengunjung merasakan perasaan yang berbeda dengan resort yang lain, dan sebagian kecil yaitu 4 responden 


\section{StrategiC}

$(6,7 \%)$ menyatakan ragu-ragu pada kenyamanan suasana di resort\&spa Kampung Sampireun.

Berdasarkan pernyataan responden tersebut dapat diketahui bahwa hampir seluruhnya yaitu $96,65 \%\{(38,3+55,0+(6,7: 2)\}$ dari 60 responden menyatakan bahwa suasana resort\&spa Kampung Sampireun sudah nyaman.

\section{c. Tanggapan Responden Terhadap Pemberian Rewards}

Berdasarkan hasil pengolahan data yang diambil dari jawaban pertanyaan-pertanyaan dalam angket yang diberikan kepada 60 responden, maka dapat diperoleh hasil mengenai tanggapan responden terhadap pemberian reward (potongan harga) yang diberikan resort\&spa Kampung Sampireun disajikan pada Tabel 13 berikut. Tabel 13

Tanggapan Responden terhadap Pemberian Rewards di Resort\&Spa Kampung Sampireun

\begin{tabular}{|c|c|c|c|c|}
\hline Pernyataan & $\begin{array}{l}\text { Alternatif } \\
\text { Jawaban }\end{array}$ & $F$ & $\%$ & Skor \\
\hline \multirow{5}{*}{$\begin{array}{l}\text { Pemberian } \\
\text { reward } \\
\text { (potongan } \\
\text { harga) }\end{array}$} & Sangat Menarik & 22 & 36,7 & 110 \\
\hline & Menarik & 29 & 48,3 & 116 \\
\hline & Ragu-Ragu & 9 & 15,0 & 27 \\
\hline & Tidak Menarik & 0 & 0 & 0 \\
\hline & $\begin{array}{l}\text { Sangat Tidak } \\
\text { Menarik }\end{array}$ & 0 & 0 & 0 \\
\hline \multicolumn{2}{|c|}{ Total } & 60 & 100 & 253 \\
\hline
\end{tabular}

Sumber: Hasil Pengolahan Data 2008

Berdasarkan Tabel 4.15 di atas dapat diperoleh gambaran tanggapan responden mengenai pemberian reward oleh resort\&spa Kampung Sampireun memperoleh skor sebesar 253 yang terdiri dari hampir setenghnya yaitu 29 responden $(48,3,0 \%)$ menyatakan menarik, $22 \quad(36,7 \%)$ responden menyatakan sangat menarik dengan adanya pemberian kejutan, sedangkan sebagian kecil yaitu 9 responden $(15,0 \%)$ menyatakan raguragu pada pemberian kejutan ini.

Berdasarkan pernyataan responden tersebut dapat diketahui bahwa hampir seluruhnya yaitu $92,5 \%\{(36,7+48,3+(15,0: 2)\}$ dari 60 responden menyatakan bahwa pemberian reward oleh resort\&spa Kampung Sampireun sudah menarik.

\section{Tanggapan Responden Terhadap Think di Resort\&Spa Kampung Sampireun}

a. Tanggapan Responden Terhadap Pemberian Nama (Logo)

Berdasarkan hasil pengolahan data yang diambil dari jawaban pertanyaan-pertanyaan dalam angket yang diberikan kepada 60 responden, maka dapat diperoleh hasil mengenai tanggapan responden terhadap pemberian nama (logo) resort\&Spa Kampung Sampireun disajikan pada Tabel 14 berikut.

Tabel 14

Tanggapan Responden terhadap Pemberian Nama (Logo) Resort\&Spa Kampung Sampireun

\begin{tabular}{|c|c|c|c|c|}
\hline Pernyataan & $\begin{array}{l}\text { Alternatif } \\
\text { Jawaban }\end{array}$ & $\mathbf{F}$ & $\%$ & Skor \\
\hline \multirow{5}{*}{$\begin{array}{l}\text { Pemberian } \\
\text { nama (logo) } \\
\text { resort\&spa } \\
\text { Kampung } \\
\text { Sampireun }\end{array}$} & Sangat Menarik & 14 & 23,3 & 70 \\
\hline & Menarik & 29 & 48,3 & 116 \\
\hline & Ragu-Ragu & 16 & 26,7 & 48 \\
\hline & Tidak Menarik & 1 & 1,7 & 2 \\
\hline & $\begin{array}{l}\text { Sangat Tidak } \\
\text { Menarik }\end{array}$ & 0 & 0 & 0 \\
\hline \multicolumn{2}{|c|}{ Total } & 60 & 100 & 236 \\
\hline
\end{tabular}

Sumber: Hasil Pengolahan Data 2008

Berdasarkan Tabel 4.17 di atas dapat diperoleh gambaran tanggapan responden mengenai pemberian nama (logo) resort\&spa Kampung Sampireun memperoleh skor sebesar 236 yang terdiri dari hampir setenghnya yaitu 29 responden $(48,3 \%)$ menyatakan menarik, sebagian kecil yaitu 14 responden $(23,3 \%)$ menyatakan sangat menarik dengan pemberian nama resort\&spa Kampung Sampireun dan logo yang unik juga dengan slogannya "back to natur". Dan hampir setenghnya yaitu 16 responden $(26,7 \%)$ menyatakan raguragu, dan sebagian kecil yaitu 1 responden $(1,7 \%)$ menyatakan tidak tertarik.

Berdasarkan pernyataan responden tersebut dapat diketahui bahwa hampir seluruhnya yaitu $84,95 \%\{(23,3+48,3+(26,7: 2)\}$ dari 60 responden menyatakan bahwa logo/slogan resort \&spa Kampung Sampireun sudah menarik.

\section{b. Tanggapan Responden Terhadap Kejelasan Promosi}

Tabel 15

Tanggapan Responden terhadap Kejelasan Promosi Resort\&Spa Kampung Sampireun

\begin{tabular}{|l|l|c|c|c|}
\hline Pernyataan & $\begin{array}{c}\text { Alternatif } \\
\text { Jawaban }\end{array}$ & $\mathbf{F}$ & $\mathbf{\%}$ & Skor \\
\hline \multirow{2}{*}{$\begin{array}{l}\text { Kejelasan } \\
\text { promosi } \\
\text { yang } \\
\text { disampaikan } \\
\text { melalui iklan } \\
\text { tv, internet, } \\
\text { dan brosur }\end{array}$} & Sangat Jelas & 21 & 35,0 & 105 \\
\cline { 2 - 5 } & Jelas & 28 & 46,7 & 108 \\
\cline { 2 - 5 } & Ragu-Ragu & 10 & 18,3 & 30 \\
\hline \multicolumn{2}{|l|}{ Tidak Jelas } & 1 & 1,7 & 2 \\
\hline \multicolumn{2}{|l}{ Total } & 0 & 0 & 0 \\
\hline
\end{tabular}

Sumber: Hasil Pengolahan Data 2008 


\section{StrategiC}

Berdasarkan hasil pengolahan data yang diambil dari jawaban pertanyaan-pertanyaan dalam angket yang diberikan kepada 60 responden, maka dapat diperoleh hasil mengenai tanggapan responden terhadap kejelasan promosi yang dilakukan resort\&Spa Kampung Sampireun disajikan pada Tabel.

Berdasarkan Tabel 4.17 di atas dapat diperoleh gambaran tanggapan responden mengenai kejelasan promosi yang disampaikan melalui iklan tv, internet, dan brosur memperoleh skor sebesar 245 yang terdiri dari hampir setenghnya yaitu 28 responden $(46,7 \%)$ menyatakan jelas, hampir setenghnya yaitu 21 responden $(35,0 \%)$ menyatakan sangat jelas terhadap kejelasan promosi yang disampaikan oleh resort\&spa Kampung Sampireun melalui iklan tv, internet juga brosur. Sebagian kecil yaitu 10 responden (18,3\%) menyatakan ragu-ragu, dan sebagian kecil yaitu 1 $(1,7 \%)$ menyatakan tidak jelas.

Berdasarkan pernyataan responden tersebut dapat diketahui bahwa hampir seluruhnya yaitu $90,85 \%\{(35,0+46,7+(18,3: 2)\}$ dari 60 responden menyatakan bahwa kejelasan promosi yang dilakukan oleh resort\&spa Kampung Sampireun sudah jelas.

\section{Tanggapan Responden Terhadap Act di Resort\&Spa Kampung Sampireun}

a. Tanggapan Responden Terhadap Tingkat Intensitas Kunjungan

Berdasarkan hasil pengolahan data yang diambil dari jawaban pertanyaan-pertanyaan dalam angket yang diberikan kepada 60 responden, maka dapat diperoleh hasil mengenai tanggapan responden terhadap tingkat intensitas terhadap kunjungan ke resort\&Spa Kampung Sampireun disajikan pada Tabel 16 berikut ini.

Tabel 16

Tanggapan Responden terhadap Tingkat Intensitas Kunuungan ke Resort\&Spa Kampung Sampireun

\begin{tabular}{|c|c|c|c|c|}
\hline Pernyataan & $\begin{array}{l}\text { Alternatif } \\
\text { Jawaban }\end{array}$ & $F$ & $\%$ & Skor \\
\hline \multirow{5}{*}{$\begin{array}{l}\text { Tingkat } \\
\text { intensitas } \\
\text { kunjungan ke } \\
\text { resort\&spa } \\
\text { Kampung } \\
\text { Sampireun }\end{array}$} & Sangat Sering & 3 & 5,0 & 15 \\
\hline & Sering & 40 & 66,7 & 160 \\
\hline & Ragu-Ragu & 17 & 28,3 & 51 \\
\hline & Tidak Sering & 0 & 0 & 0 \\
\hline & Tidak Pernah & 0 & 0 & 0 \\
\hline \multicolumn{2}{|c|}{ Total } & 60 & 100 & 226 \\
\hline
\end{tabular}

Sumber: Hasil Pengolahan Data 2008
Berdasarkan Tabel 4.18 di atas dapat diperoleh gambaran tanggapan responden mengenai tingkat intensitas kunjungan ke resort\&spa Kampung Sampireun memperoleh skor sebesar 226 yang terdiri dari sebagian besar yaitu 40 responden $(66,7 \%)$ menyatakan sering, sebagian kecil yaitu 3 responden $(5,0 \%)$ menyatakan sangat sering. Hal ini terbukti bahwa pengunjung yang datang adalah pengunjung yang loyal. Dan hampir setenghnya yaitu 17 responden $(28,3 \%)$ menyatakan raguragu.

Berdasarkan pernyataan responden tersebut dapat diketahui bahwa hampir seluruhnya yaitu $85,85 \%\{(5,0+66,7+(28,3: 2)\}$ dari 60 responden menyatakan sering berkunjungan resort\&spa Kampung Sampireun.

\section{b. Tanggapan Responden Terhadap Kesesu- aian Kunjungan dengan Gaya Hidup}

Berdasarkan hasil pengolahan data yang diambil dari jawaban pertanyaan-pertanyaan dalam angket yang diberikan kepada 60 responden, maka dapat diperoleh hasil mengenai tanggapan responden terhadap kesesuaian kunjungan ke resort\&Spa Kampung Sampireun dengan gaya hidup disajikan pada Tabel 17 berikut ini.

\section{Tabel 17}

Tanggapan Responden terhadap Kejelasan Promosi Resort\&Spa Kampung Sampireun

\begin{tabular}{|c|c|c|c|c|}
\hline Pernyataan & $\begin{array}{l}\text { Alternatif } \\
\text { Jawaban }\end{array}$ & $F$ & $\%$ & Skor \\
\hline \multirow{5}{*}{$\begin{array}{l}\text { Kesesuaian } \\
\text { kunjungan } \\
\text { dengan gaya } \\
\text { hidup }\end{array}$} & Sangat Sesuai & 7 & 11,7 & 35 \\
\hline & Sesuai & 37 & 61,7 & 148 \\
\hline & Ragu-Ragu & 16 & 26,7 & 42 \\
\hline & Tidak Sesuai & 0 & 0 & 0 \\
\hline & $\begin{array}{l}\text { Sangat Tidak } \\
\text { Sesuai }\end{array}$ & 0 & 0 & 0 \\
\hline \multicolumn{2}{|c|}{ Total } & 60 & 100 & 225 \\
\hline
\end{tabular}

Sumber: Hasil Pengolahan Data 2008

Berdasarkan Tabel 4.19 di atas dapat diperoleh gambaran tanggapan responden mengenai Kesesuaian kunjungan ke resort\&spa Kampung Sampireun dengan gaya hidup memperoleh skor sebesar 225 yang terdiri dari sebagian besar yaitu 37 responden $(61,7 \%)$ menyatakan sesuai dengan gaya hidup, sebagian kecil yaitu 7 responden $(11,7 \%)$ menyatakan sangat sesuai, dan hampir setenghnya yaitu 16 responden (26,7\%) menyatakan ragu-ragu. Dapat diketahui bahwa hampir seluruhnya yaitu $85,85 \%\{(61,7+5,0+$ $(28,3: 2)\}$ dari 60 responden menyatakan sering berkunjungan resort\&spa Kampung Sampireun. 


\section{StrategiC}

\section{c. Tanggapan Responden Terhadap Image yang Disampaikan}

Berikut ini Tabel 18 yang menggambarkan tanggapan responden terhadap image yang dihadirkan resort\&spa Kampung Sampireun.

Tabel 18

Tanggapan Responden terhadap Tingkat Intensitas Kunuungan ke Resort\&Spa Kampung Sampireun

\begin{tabular}{|c|c|c|c|c|}
\hline Pernyataan & $\begin{array}{c}\text { Alternatif } \\
\text { Jawaban }\end{array}$ & $F$ & $\%$ & Skor \\
\hline \multirow{5}{*}{$\begin{array}{l}\text { Image yang } \\
\text { berusaha } \\
\text { dihadirkan } \\
\text { oleh } \\
\text { resort\&spa } \\
\text { Kampung } \\
\text { Sampireun }\end{array}$} & Sangat Baik & 21 & 35,0 & 105 \\
\hline & Baik & 35 & 58,3 & 140 \\
\hline & Ragu-Ragu & 4 & 6,7 & 12 \\
\hline & Tidak Baik & 0 & 0 & 0 \\
\hline & $\begin{array}{l}\text { Sangat Tidak } \\
\text { Baik }\end{array}$ & 0 & 0 & 0 \\
\hline \multicolumn{2}{|c|}{ Total } & 60 & 100 & 183 \\
\hline
\end{tabular}

Sumber: Hasil Pengolahan Data 2008

Berdasarkan Tabel 4.20 di atas dapat diperoleh gambaran tanggapan responden mengenai Image yang berusaha dihadirkan oleh resort\&spa Kampung Sampireun memperoleh skor sebesar 183 yang terdiri dari sebagain besar yaitu 35 responden $(58,3 \%)$ menyatakan baik, hampir setenganya yaitu 21 responden (35,0\%) menyatakan sangat baik. Hal ini terbukti bahwa pengunjung sudah percaya pada citra perusahaan sehingga image yang dihadirkan sudah baik. Sebagian kecil yaitu 4 responden $(6,7 \%)$ menyatakan ragu-ragu. Dapat diketahui bahwa hampir seluruhnya yaitu $96,65 \%\{(35,0+58,3+$ $(6,7: 2)\}$ dari 60 responden menyatakan image resort\&spa Kampung Sampireun sudah baik.

\section{Tanggapan Responden Terhadap Relate di Resort\&Spa Kampung Sampireun}

a. Tanggapan Responden Terhadap Bagian dari Penggemar

Tabel 19

Tanggapan Responden terhadap Bagian dari Penggemar Resort\&Spa Kampung Sampireun

\begin{tabular}{|c|c|c|c|c|}
\hline Pernyataan & $\begin{array}{l}\text { Alternatif } \\
\text { Jawaban }\end{array}$ & $F$ & $\%$ & Skor \\
\hline \multirow{5}{*}{$\begin{array}{l}\text { Secara } \\
\text { keseluruhan } \\
\text { anda merasa diri } \\
\text { anda sebagai } \\
\text { bagian dari } \\
\text { penggemar yang } \\
\text { berkunjung ke } \\
\text { resort\&spa } \\
\text { Kampung } \\
\text { Sampireun }\end{array}$} & Sangat Setuju & 12 & 18,3 & 60 \\
\hline & Setuju & 34 & 56,7 & 136 \\
\hline & Ragu-Ragu & 14 & 25,0 & 42 \\
\hline & Tidak Setuju & 0 & 0 & 0 \\
\hline & $\begin{array}{l}\text { Sangat Tidak } \\
\text { Setuju }\end{array}$ & 0 & 0 & 0 \\
\hline \multicolumn{2}{|c|}{ Total } & 60 & 100 & 238 \\
\hline
\end{tabular}

Sumber: Hasil Pengolahan Data 2008
Berdasarkan Tabel 4.21 di atas dapat diperoleh gambaran tanggapan responden mengenai kegemaran pengunjung sabagai bagian dari penggemar resort\&spa Kampung Sampireun memperoleh skor sebesar 238 yang terdiri dari sebagian besar yaitu 34 responden $(56,7 \%)$ menyatakan setuju, hampir setenghnya yaitu 12 responden $(18,3 \%)$ menyatakan sangat setuju. Hal ini membuktikan adanya kesetiaan pengunjung pada perusahaan. Dan hampir setenghnya yaitu 14 responden $(25,0 \%)$ menyatakan ragu-ragu. Dapat diketahui bahwa hampir seluruhnya yaitu $87,5 \%$ $\{(18,3+56,7+(25,0: 2)\}$ dari 60 responden menyatakan bagian dari penggemar resort\&spa Kampung Sampireun.

\section{b. Tanggapan Responden Terhadap Kesesuaian Harga}

Berdasarkan hasil pengolahan data yang diambil dari jawaban pertanyaan-pertanyaan dalam angket yang diberikan kepada 60 responden, maka diperoleh hasil sebagai berikut:

Tabel 20

Tanggapan Responden terhadap Kesesuaian Harga di Resort\&Spa Kampung Sampireun

\begin{tabular}{|c|c|c|c|c|}
\hline Pernyataan & $\begin{array}{l}\text { Alternatif } \\
\text { Jawaban }\end{array}$ & $F$ & $\%$ & Skor \\
\hline \multirow{5}{*}{$\begin{array}{l}\text { Kesesuaian } \\
\text { kunjungan } \\
\text { dengan gaya } \\
\text { hidup }\end{array}$} & Sangat Sesuai & 7 & 11,7 & 35 \\
\hline & Sesuai & 37 & 61,7 & 148 \\
\hline & Ragu-Ragu & 16 & 26,7 & 42 \\
\hline & Tidak Sesuai & 0 & 0 & 0 \\
\hline & $\begin{array}{l}\text { Sangat Tidak } \\
\text { Sesuai }\end{array}$ & 0 & 0 & 0 \\
\hline \multicolumn{2}{|c|}{ Total } & 60 & 100 & 225 \\
\hline
\end{tabular}

Sumber: Hasil Pengolahan Data 2008

Tanggapan responden mengenai harga yang ditawarkan sesuai dengan kemampuan daya beli yang disanggupi pengunjung memperoleh skor sebesar 232 yang terdiri dari sebagaian besar yaitu 37 responden $(61,7 \%)$ menyatakan sesuai, dan 7 responden $(11,7 \%)$ menyatakan sangat sesuai, hampir setenghnya yaitu 16 responden $(26,7 \%)$ menyatakan ragu-ragu dikarenakan banyak kebutuhan lain. Dapat diketahui bahwa hampir seluruhnya yaitu $86,75 \%\{(11,7+61,7+(26,7: 2)\}$ dari 60 responden menyatakan harga yang ditawarkan oleh resort\&spa Kampung Sampireun sudah sesuai.

Tabel berikut ini menyajikan data rekapitulasi tanggapan responden terhadap Pemasaran Eksperiensial pada Resort\&Spa Kampung Sampireun Garut. 


\section{StrategiC}

Tabel 21

Rekapitulasi Skor Tanggapan Responden Mengenai Pemasaran Eksperiensial pada Resort\&Spa Kampung Sampireun Garut

\begin{tabular}{|c|c|c|c|c|}
\hline \multirow{2}{*}{ No } & \multirow{2}{*}{ VARIABEL/DIMENSI } & \multicolumn{3}{|c|}{ Skor Penilaian } \\
\hline & & Perolehan Skor & Skor Ideal & $\%$ \\
\hline & PEMASARAN EKSPERIENSIAL & & & \\
\hline \multirow{7}{*}{1} & Sense & & & \\
\hline & Dekorasi Tata Ruang & 239 & 300 & 79,67 \\
\hline & Penyelenggaraan musik tradisional & 241 & 300 & 80,33 \\
\hline & Lokasi atau Tempat & 260 & 300 & 86,67 \\
\hline & Menu yang disajikan & 240 & 300 & 80,00 \\
\hline & Kelayakan kondisi peralatan & 240 & 300 & 80,00 \\
\hline & Total Skor Sense & 1220 & 1500 & 81,33 \\
\hline \multirow{5}{*}{2} & Feel & & & \\
\hline & Perasaan setelah berkunjung & 235 & 300 & 78,33 \\
\hline & Suasana & 259 & 300 & 86,33 \\
\hline & Pemberian Reward (potongan harga) & 240 & 300 & 80,00 \\
\hline & Total Skor Feel & 734 & 900 & 81,56 \\
\hline \multirow{4}{*}{3} & Think & & & \\
\hline & Pemberian nama $(\log 0)$ & 236 & 300 & 78,67 \\
\hline & Kejelasan promosi & 245 & 300 & 81,67 \\
\hline & Total Skor Think & 481 & 600 & 80,16 \\
\hline \multirow{5}{*}{4} & Act & & & \\
\hline & Tingkat intensitas kunjungan & 226 & 300 & 75,33 \\
\hline & Kesesuaian kunjungan pada gaya hidup & 225 & 300 & 75,00 \\
\hline & Image yang dihadirkan resort\&spa Kampung Sampireun & 183 & 300 & 61,00 \\
\hline & Total Skor Act & 634 & 900 & 70,44 \\
\hline \multirow{5}{*}{5} & Relate & & & \\
\hline & Anda merasa bagian dari penggemar resort\&spa Kampung Sampireun & 238 & 300 & 79,33 \\
\hline & Kesesuian harga yang ditawarkan & 232 & 300 & 77,33 \\
\hline & Total Skor Relate & 470 & 600 & 78,33 \\
\hline & Total Skor Pemasaran Eksperiensial & 3539 & 4500 & 78,64 \\
\hline
\end{tabular}

Sumber: Berdasarkan Hasil Pengolahan Data 2008

Berdasarkan Tabel 21 di atas, variabel $X$ (Pemasaran eksperiensial) memperoleh jumlah skor sebesar 3539, apabila di presentasekan dengan skor ideal maka diperoleh presentase $78,64 \%$, yang berkategori baik.

\section{Tanggapan Responden Terhadap Retensi Pelanggan Resort\&Spa Kampung sampi- reun}

Penjelasan dari masing-masing dimensi Retensi Pelanggan yang terdiri dari trust, satisfaction dan commitment pada resort\&spa Kampung Sampireun dirangkum dalam Tabel rekapitulasi yang tercantum pada Tabel di bawah ini, sehingga dapat dilihat perbandingan total skor pada masing-masing dimensi tersebut.

Tabel 22

Rekapitulasi Skor Tanggapan Responden Mengenai Retensi Pelanggan pada Resort\&Spa Kampung Sampireun Garut

\begin{tabular}{|c|c|c|c|c|}
\hline \multirow{2}{*}{ No } & \multirow{2}{*}{ VARIABEL/DIMENSI } & \multicolumn{3}{|c|}{ Skor Penilaian } \\
\hline & & Perolehan Skor & Skor Ideal & $\%$ \\
\hline & RETENSI PELANGGAN & & & \\
\hline \multirow{5}{*}{1} & Trust & & & \\
\hline & Keamanan yang dilakukan oleh resort\&spa Kampung Sampireun & 234 & 300 & 78,00 \\
\hline & Kenyamanan selama di resort\&spa Kampung Sampireun & 252 & 300 & 84,00 \\
\hline & Pengaruh nama yang tekenal & 244 & 300 & 81,33 \\
\hline & Total Skor Trust & 730 & 900 & 81,11 \\
\hline \multirow{4}{*}{2} & Satisfaction & & & \\
\hline & Kecepatan pelayanan di resort\&spa Kampung Sampireun & 241 & 300 & 80,33 \\
\hline & Keramahan dan kesopanan pelayanan & 242 & 300 & 80,67 \\
\hline & Total Skor Satisfaction & 483 & 600 & 80,5 \\
\hline
\end{tabular}




\begin{tabular}{|c|c|c|c|c|}
\hline \multirow{2}{*}{ No } & \multirow{2}{*}{ VARIABEL/DIMENSI } & \multicolumn{3}{|c|}{ Skor Penilaian } \\
\hline & & Perolehan Skor & Skor Ideal & $\%$ \\
\hline \multirow{4}{*}{3} & Commitment & & & \\
\hline & Fasilitas discount berkala & 224 & 300 & 74,67 \\
\hline & Pembelian room di weekday & 241 & 300 & 80,33 \\
\hline & Maintenance pelanggan & 220 & 300 & 73,33 \\
\hline \multicolumn{2}{|r|}{ Total Skor Commitment } & 685 & 900 & 76,11 \\
\hline \multicolumn{2}{|r|}{ Total Skor Retensi Pelanggan } & 1898 & 2400 & 79,08 \\
\hline
\end{tabular}

Sumber: Berdasarkan Hasil Pengolahan Data 2008

Berdasarkan Tabel 22 di atas, variabel $Y$ (Retensi Pelanggan) memperoleh jumlah skor sebesar 1.898, apabila di presentasekan dengan skor ideal maka diperoleh presentase $79,08 \%$ yang artinya menurut Moh. Ali ke dalam kategori baik.

\section{HASIL PENGUJIAN HIPOTESIS}

Pada penelitian ini terdapat lima hipotesis yang diuji yaitu pengaruh sense terhadap retensi pelanggan, pengaruh Feel terhadap retensi pelanggan, pengaruh Think terhadap retensi pelanggan, pengaruh Act terhadap retensi pelanggan, dan pengaruh Relate terhadap retensi pelanggan.

Pengujian hipotesis dilakukan dengan bantuan software SPSS 15 dan menggunakan uji statistik path analysis (analisis jalur). Hasil penelitian yang diperoleh akan menunjukkan pengaruh yang diberikan variabel independen terhadap variabel dependen baik secara langsung maupun tidak langsung.

Tabel 23

Matrik Korelasi antara Dimensi Pemasaran Eksperiensial Dengan Retensi Pelanggan

\begin{tabular}{|l|l|l|l|l|l|l|}
\hline & $\mathbf{Y}$ & $\mathbf{X}_{\mathbf{1}}$ & $\mathbf{X}_{\mathbf{2}}$ & $\mathbf{X}_{\mathbf{3}}$ & $\mathbf{X}_{\mathbf{4}}$ & $\mathbf{X}_{\mathbf{5}}$ \\
\hline $\mathbf{Y}$ & 1,000 & 0,644 & 0,539 & 0,359 & 0,253 & 0,396 \\
\hline $\mathbf{X}_{\mathbf{1}}$ & $\mathbf{0 , 6 4 4}$ & 1,000 & 0,796 & 0,436 & 0,362 & 0,279 \\
\hline $\mathbf{X}_{\mathbf{2}}$ & 0,539 & $\mathbf{0 , 7 9 6}$ & 1,000 & 0,348 & 0,243 & 0,133 \\
\hline $\mathbf{X}_{\mathbf{3}}$ & 0,359 & 0,436 & 0,348 & 1,000 & 0,337 & 0,289 \\
\hline $\mathbf{X}_{\mathbf{4}}$ & 0,253 & 0,362 & 0,243 & 0,337 & 1,000 & 0,189 \\
\hline $\mathbf{X}_{\mathbf{5}}$ & 0,396 & 0,279 & 0,133 & 0,289 & 0,189 & 1,000 \\
\hline
\end{tabular}

Sumber: Hasil pengolahan Data 2008

Berdasarkan hasil pengujian hipotesis diketahui bahwa korelasi terbesar antara setiap dimensi $X$ dengan $Y$ diperoleh sense sebagai $\left(X_{1}\right)$ dan retensi pelanggan sebagai $(Y)$ dengan nilai 0,644 . Berdasarkan interprestasi koefisien korelasi menunjukan bahwa terdapat hubungan yang sangat kuat antara dimensi sense dengan retensi pelanggan. Sedangkan nilai koefisien korelasi terbesar antar setiap dimensi $X$ dimiliki oleh pada korelasi antara sense $\left(X_{1}\right)$ dan feel $\left(X_{2}\right)$ dengan nilai 0,796 . Hal tersebut menunjukan bahwa terdapat hubungan yang signifikan antara sense dengan feel.

Berdasarkan hasil pengujian untuk uji $\mathrm{F}$ melalui program SPSS 15 diperoleh data pengujian keseluruhan pada tabel Anova menunjukkan tingkat signifikan, yang menunjukkan $F_{\text {hitung }}>F_{\text {tabel, }}$ yaitu 82,505> 3,479 sehingga dapat diambil kesimpulan Ho ditolak oleh karena itu pengujian secara individual dapat dilakukan.

Adapun untuk pengujian koefisien jalur setiap variabel diperoleh dalam Tabel 24 berikut ini.

Tabel 24

Hasil Pengujian Koefisien Jalur

\begin{tabular}{|c|c|c|c|c|}
\hline \multicolumn{2}{|c|}{ Koefisien Jalur } & thitung & $t_{\text {tabel }}$ & Kesimpulan \\
\hline PYX.1 & 0,350 & 3,950 & 2,00 & Ho Ditolak \\
\hline PYX.2 & 0,342 & 4,730 & 2,00 & Ho Ditolak \\
\hline PYX.3 & 0,166 & 2.259 & 2,00 & Ho Ditolak \\
\hline PYX.4 & 0,186 & 2,650 & 2,00 & Ho Ditolak \\
\hline PYX.5 & 0,071 & 2,990 & 2,00 & Ho Ditolak \\
\hline
\end{tabular}

Sumber : Hasil Pengolahan Data 2008

Berdasarkan hasil pengujian koefisien jalur diperoleh pengaruh sense terhadap retensi pelanggan memiliki nilai 0,350 , pengaruh feel terhadap retensi pelanggan memiliki nilai 0,342 , pengaruh think terhadap retensi pelanggan memiliki nilai 0,166 , pengaruh act terhadap retensi pelanggan memiliki nilai 0,186 , dan pengaruh relate terhadap retensi pelanggan memiliki nilai 0,071 . Pengaruh terbesar ada pada pengaruh sense terhadap retensi pelanggan, thitung yang diperoleh dengan tingkat signifikansi 0.05 yaitu $3,950,4,730,2,259,2,650,2,990$ dengan $t_{\text {tabel }}$ 2,00. Jadi dapat disimpulkan bahwa $X_{1}, X_{2}, X_{3}, X_{4}$, dan $X_{5}$ Ho ditolak yang artinya terdapat pengaruh antara sense, feel, think, act, dan relate terhadap retensi pelanggan.

Adapun hasil pengujian seluruh pengaruh pemasaran eksperiensial terhadap retensi 


\section{StrategiC}

pelanggan disajikan pada Tabel 25 sebagai berikut ini.

Tabel 25

Hasil Pengujian Pengaruh Pemasaran Eksperiensial terhadap Retensi Pelanggan

\begin{tabular}{|c|c|c|c|c|}
\hline $\begin{array}{l}\text { Pengaruh } \\
\text { Variabel }\end{array}$ & $\begin{array}{l}\text { Koef. } \\
\text { Jalur }\end{array}$ & $\begin{array}{l}\text { Pengaruh } \\
\text { Langsung }\end{array}$ & $\begin{array}{l}R^{2} Y_{1} \\
\ldots, Y X_{5}\end{array}$ & $\begin{array}{l}\text { Pengujian } \\
\text { Hipotesis }\end{array}$ \\
\hline$X_{1}$ terhadap $Y$ & 0,350 & 12,25 & 27,36 & Ho Ditolak \\
\hline $\mathrm{X}_{2}$ terhadap $\mathrm{Y}$ & 0,342 & 11,70 & 24,48 & Ho Ditolak \\
\hline $\mathrm{X}_{3}$ terhadap $\mathrm{Y}$ & 0,166 & 2,76 & 8,77 & Ho Ditolak \\
\hline $\mathrm{X}_{4}$ terhadap $\mathrm{Y}$ & 0,186 & 3,46 & 8,66 & Ho Ditolak \\
\hline$X_{5}$ terhadap $Y$ & 0,071 & 0,50 & 2,1 & Ho Ditolak \\
\hline \multicolumn{3}{|c|}{$\mathbf{R}^{2}$} & 71,37 & \\
\hline
\end{tabular}

Sumber : Hasil Pengolahan Data 2008

Berdasarkan hasil perhitungan di atas maka pengaruh pemasaran eksperiensial termasuk kategori kuat, untuk koefisien jalur variabel lainnya diluar variabel $X_{1}, X_{2}, X_{3}, X_{4}$ dan $X_{5}$ ditentukan melalui:

$$
\begin{aligned}
P_{Y} \mathcal{E}_{1} & =\sqrt{1-R_{Y(X 1, X 2, X 3, X 4, X 5)}^{2}} \\
& =\sqrt{1-0,7137} \\
& =0,5351
\end{aligned}
$$

Artinya $X_{1}, X_{2}, X_{3}, X_{4}$, dan $X_{5}$, secara bersamasama mempengaruhi $Y$ adalah $71,37 \%$ dan sisanya sebesar $(0,5351)^{2}=0,2863 \times 100 \%=$ $28,63 \%$ dipengaruhi faktor lain yang tidak termasuk ke dalam penelitian yaitu comodities marketing, goods marketing, services marketing dan transfor marketing. Berdasarkan hasil pengujian diatas dapat disimpulkan seperti data pada Tabel 26 di bawah ini.

Berdasarkan data pada Tabel diatas dapat dilihat kesimpulan dari pengolahan analisis path retensi pelanggan. Dapat dilihat nilai pengaruh langsung dari $\mathrm{X}$ terhadap $\mathrm{Y}$, nilai pengaruh tidak langsung, nilai total pengaruh dan nilai thitung terhadap alpha dengan tingkat kesalah 0.05 sehingga dapat disimpulkan keseluruhan $\mathrm{Ho}$ ditolak dan Hi diterima. Sehingga disimpulkan bahwa adanya pengaruh pemasaran eksperiensial terhadap retensi pelanggan pada Resort\&Spa Kampung Sampireun.

\section{SIMPULAN DAN SARAN}

\section{Simpulan}

Berdasarkan hasil penelitian yang dilakukan oleh peneliti melalui analisis deskriptif dan verifikatif dengan menggunakan path analysis, maka berdasarkan penelitian tersebut dapat diambil kesimpulan sebagai berikut:

1. Tanggapan responden terhadap pemasaran eksperiensial hampir seluruhnya sudah baik. $\mathrm{Hal}$ ini dapat dilihat dari indikator yang paling dominan sampai kepada indikator yang paling rendah, indikator yang paling dominan adalah persepsi responden terhadap eksperensial pada dimensi sense memperoleh tanggapan yang baik dari pengunjung, sedangkan indikator yang paling rendah adalah relate yang ditinjau dari kesesuaian harga yang ditawarkan resort\&spa Kampung Sampireun.

2. Tanggapan responden terhadap retensi pelanggan hampir seluruhnya sudah baik. Hal ini dapat dilihat dari indikator yang paling dominan sampai kepada indikator yang paling rendah, indikator yang paling dominan adalah

\begin{tabular}{|c|c|c|c|c|c|c|c|c|c|c|}
\hline \multirow[b]{2}{*}{$X$} & \multirow{2}{*}{$\begin{array}{c}\text { Pengaruh } \\
\text { Langsung } \\
\text { Terhadap } \\
Y\end{array}$} & \multicolumn{5}{|c|}{ Pengaruh Tidak Langsung } & \multirow{2}{*}{$\begin{array}{c}\text { Total } \\
\text { Pengaruh }\end{array}$} & \multirow{2}{*}{$\begin{array}{c}t \text { tabel 1,988 } \\
t \text { hitung }\end{array}$} & \multirow{2}{*}{$\begin{array}{c}\text { Sign } \\
\text { Alpha } \\
0,05\end{array}$} & \multirow{2}{*}{$\begin{array}{l}\text { Kepu- } \\
\text { tusan }\end{array}$} \\
\hline & & $\begin{array}{c}\text { Sense } \\
\text { (X1) }\end{array}$ & $\begin{array}{l}\text { Feel } \\
\text { (X2) }\end{array}$ & $\begin{array}{c}\text { Think } \\
\text { (X3) }\end{array}$ & $\begin{array}{l}\text { Act } \\
\text { (X4) }\end{array}$ & $\begin{array}{c}\text { Relate } \\
\text { (X5) }\end{array}$ & & & & \\
\hline $\begin{array}{c}\text { Sense } \\
\text { (X1) }\end{array}$ & 12,25 & 1,000 & 0,0953 & 0,0253 & 0,0236 & 0,0069 & 27,36 & 3,950 & 2,000 & $\begin{array}{l}\text { Ho } \\
\text { Ditolak }\end{array}$ \\
\hline $\begin{array}{l}\text { Feel } \\
\text { (X2) }\end{array}$ & 11,70 & 0,0953 & 1,000 & 0,0198 & 0,0155 & 0,0032 & 24,48 & 4,730 & 2,000 & $\begin{array}{l}\text { Ho } \\
\text { Ditolak }\end{array}$ \\
\hline $\begin{array}{c}\text { Think } \\
\text { (X3) }\end{array}$ & 2,76 & 0,0253 & 0,0198 & 1,000 & 0,0104 & 0,0034 & 8,77 & 2.259 & 2,000 & $\begin{array}{l}\text { Ho } \\
\text { Ditolak }\end{array}$ \\
\hline $\begin{array}{l}\text { Act } \\
\text { (X4) }\end{array}$ & 3,46 & 0,0236 & 0,0116 & 0,0116 & 1,000 & 0,0025 & 8,66 & 2,650 & 2,000 & $\begin{array}{l}\text { Ho } \\
\text { Ditolak }\end{array}$ \\
\hline $\begin{array}{c}\text { Relate } \\
\text { (X5) }\end{array}$ & 0,50 & 0,0069 & 0,0034 & 0,0034 & 0,0025 & 1,000 & 2,1 & 2,990 & 2,000 & $\begin{array}{l}\text { Ho } \\
\text { Ditolak }\end{array}$ \\
\hline & & & & & & & $R^{2}=$ & & & \\
\hline
\end{tabular}

Tabel 26

Hasil Pengujian Koefisien Jalur Pengaruh Langsung dan Tidak Langsung Dimensi Variabel $X$ terhadap $Y$

Sumber: Hasil Pengolahan Data 2008

pengaruh pemasaran eksperiensial terhadap persepsi responden terhadap trust memperoleh 
tanggapan yang baik dari pengunjung, sedangkan indikator yang paling rendah adalah saitsfaction yang ditinjau dari kecepatan pelayanan.

3. Pemasaran Eksperiensial berpengaruh secara positif terhadap Retensi pelanggan. Sehingga produk dan jasa yang berkualitas, inovatif dan memberikan kenyamanan juga kepuasan yang baik pada pengunjung akan memberikan pengaruh yang positif terhadap retensi pelanggan.

Secara keseluruhan berdasarkan hasil pengolahan data menunjukan pada umumnya pemasaran eksperiensial yang terdiri dari sense, feel, think, act, dan relate berpengaruh terhadap retensi pelanggan resort\&spa Kampung Sampireun.

\section{Saran}

Saran penulis untuk meningkatkan dan mempertahankan retensi pelanggan resort\&spa Kampung Sampireun, maka resort\&spa Kampung Sampireun harus mempertahankan hasil-hasil positif yang telah dicapai dan meningkatkan kualitas dengan memberikan pengalaman yang positif kepada pengunjung yang selama ini telah dilaksanakan dengan pengalaman tersebut dapat merangsang panca indera, emosi, cognitive, tingkah laku dan nilai hubungan yang menggantikan niali fungsional. Berdasarkan hasil penelitian, maka penulis merekomendasikan halhal berikut:

1. Penilaianan pelanggan terhadap kesesuaian harga yang ditawarkan resort\&spa Kampung Sampireun dinilai tidak sesuai. Resort\&spa Kampung Sampireun harus lebih memperhatikan kebutuhan, keinginan dari pengunjung dengan memberikan pelayanan yang lebih baik supaya pengunjung merasa puas dan tidak ada rasa penyesalan dengan apa yang telah dikorbankan oleh pengunjung yaitu waktu dan biaya.

2. Upaya untuk mempertahankan pelanggan agar tidak mudah terpengaruh oleh resort-resort yang sejenis maka, resort\&spa Kampung Sampireun harus memberikan pelayanan yang optimal kepada pengunjung mulai dari keramahan sampai kecepatan pelayan/petugas dalam melayani pengunjung.

3. Berdasarkan penelitian bahwa pemasaran eksperiensial memberikan pengaruh terhadap retensi pelanggan akan tetapi resort\&spa Kampung Sampireun harus lebih memperhatikan keinginan dengan memberikan keunikan yang tidak dimiliki resort-resort lain terhadap pelanggan dengan memberikan pengalaman yang tidak akan terlupakan, dengan demikian pelanggan akan memperhatikan makna dari strategi sehingga akan membentuk citra yang positif dalam benak pelanggan dan pada akhirnya akan tercipta loyalitas dan retensi yang kuat bagi pelanggan.

\section{DAFTAR PUSTAKA}

Agus Sulastiyono. 2006. Manajemen Penyelenggaraan Hotel. Bandung: Alfabeta.

Anderson, Vince. 2000. Strategic Marketing Management. New York: Houghton Miflin Company.

Asep Hermawan. 2006. Penelitian Bisnis Paradigma Kuantitatif. Jakarta: PT Gramedia Widia Sarana Indonesia.

Barnes James. 2003. Secrets of Customer Relationship Management: Rahasia Manajemen Hubungan Pelanggan. Edisi Bahasa Indonesia. Yogyakarta: Penerbit ANDI.

Buchari Alma. 2007. Manajemen Pemasaran dan Pemasaran Jasa. Bandung: CV. Alfabeta.

Buttle, Francis. 2004. Customer Relationship Management. Heinemann Linacre House: Jordan Hill.

Engel F. James. 1994. Perilaku Konsumen. Edisi Keenam. Diterjemahkan oleh FX.Budiyanto. Jakarta: Binarupa Aksara.

Fandi Tjiptono. 2006. Pemasaran Jasa. Malang: Bayumedia.

Gregorius Chandra dan Fandy Tjiptono. 2005. Service, Qualitya and Satisfaction. Yogyakarta: Penerbit Andi.

Griffin, Jill. 2002. Customer Loyalty How To Earn, How To Keep It. Singapura: Lexington Books

Harun Al. Rasyid 1994. Teknik Penarikan Sampel dan Penyusunan Skala. Prodi IImu Sosial BKU Sosiologi Antropologi Program Pasca Sarjana. Bandung: Universitas Pajajaran

Hermawan Kartajaya. 2002. Marketing Plus Siasat Memenangkan Persaingan Global. Jakarta: PT. Erlangga

Hermawan Kartajaya. 2003. Marketing In Venus. Jakarta: PT Gramedia Pustaka 


\section{StrategiC}

Hermawan Kartajaya. 2007. Boosting Loyality Marketing Performance. Jakarta: Mizan Pustaka.

Husein Umar. 2003. Metode Riset Bisnis. Jakarta: PT Gramedia Pustaka Utama, Jakarta.

Husein Umar. 2003. Metode Riset Perilaku Organisasi. Jakarta: PT. Gramedia Pustaka Utama.

Indriantoro dan Supomo. 2002. Metodologi Penelitian Bisnis. Yogyakarta: BPFE.

Kotler dan Amstrong. 2007. Dasar-Dasar Pemasaran Edisi Kesembilan Jilid 7. Jakarta: PT Indeks.

Kotler dan Amstrong. 2007. Manajemen Pemasaran Edisi Dua Belas. Jilid 2. Jakarta: PT Indeks.

Kotler, Philip \& Kevin L. Keller. 2006. Marketing Management $12^{\text {th }}$ Edition. New Jersey: Pearson Internasional Edition - Prentice Hall.

Kotler, Philip dan Gary Armstrong. 2006. Principle of Marketing. New Jersey: Prentice Hall.

Kotler, Philip. 2005. Manajemen Pemasaran. Jilid 1 dan 2. Jakarta: Prenticehall.

Lovelock, Christopher, Jochen Wirtz, Hean Tat Keh, Xiongwan Lu. 2005. Service Marketing in Asia: Managing People, Technology, and Strategy. Edisi Kedua. Pearson, Prentice Hall

Malhotra, Naresh K. 2004. Basic Marketing Research, Application to Kontemporari Issue, International Edition. New Jersey: Pearson Edition.

Mangkunegara, A. A. Anwar Prabu. 2003. Perilaku Konsumen. Edisi Revisi. Bandung: Refika Aditama.

Moh. Nasir. 2003. Metode Penelitian. Jakarta: Ghalia Indonesia.

Oliver, L Richard. 1997. Satisfaction, A Behaviorial Perspektive On the Customer. New York: Mc Graw-Hill Companies Inc.

Peppers, Don, dan Rogers, Martha. 2004. Managing Customer Relationships. New Jersey: John Wiley and Sons.Inc, Hoboken.

Pine II, Joseph and Gilmore H James. 1999. The Experience Economy: Work Is Theatre And Every Business A Stage. Boston: Harvad Business School Press.

Rambat Lupiyoadi. 2001. Manajemen Pemasaran Jasa. Jakarta: Salemba Empat

Saladin Djalim. 2003. Manajemen Pemasaran: Analisis Perencanaan Pelaksanaan dan Pengendalian. Bandung: Linda Karya.
Schimtt, Shaun dan Wheeler Joe. 2002. Managing The Customer Experience. Prentice hall.

Schmitt, H Bernd. 1999. Experiential Marketing. New York, The free Press

Sitepu Nirwana Sk.. 1994. Analisis Jalur (Path Analysis). Bandung: Unit Pelayanan Statistika FPMIPA Universitas Padjadjaran.

Sudjana. 2001. Metode Statistika. Bandung: Tarsito.

Sugiyono, 2006. Metode Penelitian Bisnis. Bandung: CV. Alfabeta.

Suharsimi Arikunto. 2006. Prosedur Penelitian Suatu Pendekatan Praktek. Jakarta: Rineka Cipta.

Uma Sekaran. 2005. Metodologi Penelitian untuk Bisnis. Jakarta: Salemba Empat.

Wina Sanjaya. 2008. Strategi Pembelajaran. Jakarta: Kencana Prenada Media Group.

Yandianto. 2000. Kamus Umum Bahasa Indonesia. Bandung: M2S.

Yazid. 2005. Pemasaran Jasa. Yogyakarta: Ekonisia.

Zeithaml, Bitner A, Mary Jo, Bitner, Dwayne D. Gremler. 2006. Service Marketing: Integrating Customer Focus Across the Firm. Mc Graw Hill.

Jurnal

Andi dan Desi 10-16 November 2003. Starbuck Caffee. Ciptakan Tempat ketiga bagi Konsumen, PROSPEKTIF, Edisi 50, Vol 5, Halaman 22

De Wulf, Kristof, et. al.. 2001. Investment in Consumer Relationship: A Cross Country and Cross-Industry Exploration. Journal of Marketing, Vol.65, 33-38.

Kristaung, Robert. 2005. Perkembangan Relationship Marketing dan Relevansinya dalam Praktik Pemasaran Jasa. Jurnal Manajemen dan Pemasaran Jasa, Vol.1, No.1, Maret. 